NBER WORKING PAPER SERIES

\title{
INDEX FUNDS AND STOCK MARKET GROWTH
}

\author{
William N. Goetzmann \\ Massimo Massa \\ Working Paper 7033 \\ http://www.nber.org/papers/w7033
NATIONAL BUREAU OF ECONOMIC RESEARCH
1050 Massachusetts Avenue
Cambridge, MA 02138
March 1999

We thank Fidelity for providing us with data for research. We thank Y. Amihud, P. Bossaerts, J. Dermine, P. Hillion, J. Ingersoll, A. Kumar, R. Pozen, N. Prabhala, S. Ross, R. Shiller, and A. Shleifer for helpful conversations on this topic. We are also grateful to the participants to the USC and New York Fed workshops in finance. We thank $\mathrm{Z}$. Ivkovich for his contribution to an earlier draft of this paper and Fidelity for having provided us with the data. All the errors are ours. The views expressed in this paper are those of the authors and do not reflect those of the National Bureau of Economic Research.

(C) 1999 by William N. Goetzmann and Massimo Massa. All rights reserved. Short sections of text, not to exceed two paragraphs, may be quoted without explicit permission provided that full credit, including (C) notice, is given to the source. 
Index Funds and Stock Market Growth

William N. Goetzmann and Massimo Massa

NBER Working Paper No. 7033

March 1999

\begin{abstract}
In the present paper we analyze the relationship between index funds and asset prices. In particular, our analysis of daily index fund flows indicates a strong contemporaneous correlation between fund inflows and S\&P market returns. We also document a strong negative correlation between fund out flows and S\&P market returns with the exception of outflows from a fund with very high initial investment requirement. These effects may be interpreted in two ways. Either investor supply and demand affects S\&P market prices, or investors condition their demand and supply on intra-day market fluctuations. To sort out these effects, we examine trailing investor reaction to market moves. Our results suggest the market reacts to daily demand. However, only negative reactions appear due to past returns.

We investigate whether index investor demand shocks are permanent or temporary by examining the related behavior of the S\&P futures index. Clear evidence supports the hypothesis that they are permanent. This result may help explain the unusual recent relative performance of the S\&P 500 index.

Using the average market-timing newsletter recommendation over the period, we find that investors appear to react to "expert" advice about the market. Bullish newsletter sentiment is associated with greater inflows, although outflows are not well explained by newsletter advice. Dispersion in advice is associated with lower inflows. We find a high correlation among a number of variables used as a proxy for investor disagreement.

William N. Goetzmann

Yale School of Management

135 Prospect Street

P.O. Box 208200

New Haven, CT 06511

and NBER

william.goetzmann@yale.edu

Massimo Massa

INSEAD University

Fontainebleau 77305

Cedex, France

massimo.massa@insead.fr
\end{abstract}




\section{Introduction}

There is strong empirical evidence that demand and supply shocks can affect individual stock prices. Event studies focusing on compositional changes in the S\&P 500 index, for example, find that announcements of addition to the index increases share prices and delisting decreases share prices. ${ }^{1}$ Shleifer (1986) and Harris and Gurel (1986) interpret this as evidence that demand curves for stocks slope down. Lynch and Mendenhall (1997) and Beniesh and Whaley (1996) examining data since announcement and delisting days were separated, support downward-sloped demand curves, but also find that some of gains or losses due to index fund purchases or sales on the day of an addition or deletion is reversed the following day. The literature on block purchases and sales of stock generally finds evidence of temporary price pressure on individual securities conditional upon unusual demand or supply. ${ }^{2}$ Lakonishok, Shleifer and Vishny (1992) find that stocks purchased by institutions in a quarter show a significant rise. Chan and Lakonishok $(1993,1995)$ document price reactions to institutional trades. The implication of these studies is that share prices may not represent "fundamental" values but depend significantly upon how much money is invested and when.

Recent research by Warther (1995) and Zheng (1997) suggests that these supply and demand effects may aggregate to the level of the stock market itself. Zheng (1998) uses investment sector flows, including households, from 1952 to 1996 and finds that quarterly institutional demand shocks, but not household demand shocks, are contemporaneously correlated to stock market returns. Using monthly returns and flows for the mutual fund industry

\footnotetext{
${ }^{1}$ See Shleifer (1986), Garry and Goetzmann (1986) Harris and Gruel (1986), Dhillon and Johnson (1991) and Lynch and Mendenhall (1997).
} 
from 1984 to 1993, Warther (1995) finds that returns and flows are strongly contemporaneously correlated. He argues that this is not due to DeLong et al (1990) feedback trading, i.e. to that investors chasing the market by increasing inflows when the market is rising and increasing outflows when the market is falling. His argument is based on finding no lagged relationship between market returns and subsequent month net flows. Without daily data, however, he cannot reject the hypothesis that the feedback trading is simply occurring at a higher frequency that he has data. Also Fridson and Jonsson (1995) show, with quarterly data, that net inflows in highyield bond mutual funds tend to improve liquidity and reduce bond liquidity risk premia. At the very long horizon, papers by Bakshi and Chen (1994) and Constantinides, Donaldson and Mehra (1998) provide theory and evidence that the age distribution of the population is a significant determinant of the equity premium and hence stock prices relative to the riskless asset. Presumably the mechanism for such fundamental shifts in the equity premium is the gradual shift in individual demand for equities with aging.

In this paper, we use daily data on three S\&P index funds to investigate the relationship between demand shocks and the movement of the S\&P 500 index. We focus on index funds because their goal is to simply track the S\&P. As a result, index fund managers have little incentive to delay or spread-out orders to avoid adverse trading conditions. While economic gains may be had by delayed trading, tracking error is increased as well. Thus, for S\&P index funds, is possible to precisely identify the day on which flows could affect the market. In addition, we know that "speculative" flows are not based on beliefs about manager skill, but about beliefs about the stock market itself. A third advantage of focusing solely on S\&P index

\footnotetext{
${ }^{2}$ See Scholes (1972), Holthausen, Leftwich and Mayers (1984) and Michaelson and Partch (1985), for example.
} 
funds is that we know exactly what portfolio of stocks are demanded on that day and we have an index that precisely matches that portfolio.

Shiller (1997) points out a problem endemic to all studies correlating fund flows with stock price dynamics. Unless it is possible to prove that the proceeds from sales of fund shares are not re-invested in equities, then it is difficult to infer that flows out of mutual funds in fact represents a shift in sentiment about the stock market. Without individual account information, we cannot address this problem directly, since we do not know whether the inflows derived from sales of equities, or from a cash account. In the work that follows, we implicitly assume that purchases and sales reflect re-balancing towards or away from equities.

Despite the limitations of using aggregate data at the fund level, our analysis of daily index fund flows indicates a strong contemporaneous correlation between fund inflows and S\&P market returns. We also document a strong negative correlation between fund out flows and S\&P market returns with the exception of outflows from a back-end load fund. These effects may be interpreted in two ways. Either investor supply and demand affects S\&P market prices, or investors condition their demand and supply on intra-day market fluctuations. To sort out these effects, we examine trailing investor reaction to market moves. Our results suggest the market reacts to daily flows. A lack of any next-day reaction to positive market moves suggests that investors are not chasing short-term trends.

We also investigate whether index investor demand shocks are permanent or temporary. Demand shocks might simply exert temporary price pressure on S\&P 500 stocks at the end of the day that reverse themselves in the next trading session. This would be consistent with the findings by Harris and Gurel (1986) and Lynch and Mendenhall (1997) and others that stock price moves on a listing or delisting day partially reversed themselves in the next session. 
Otherwise demand shocks can be permanently incorporated in asset prices. Indeed, evidence pointing towards this direction has been found by Shleifer (1986) who has shown that the S\&P inclusion price effect is permanent. Also Garry and Goetzmann (1986) did not find any evidence of rebound in prices. Unlike all these studies we do not focus on the listing-delisting phenomenon, concentrating, instead, on the analysis of the effects of clearly identified "liquidity shocks" (flows into investment funds) on asset pricing in general.

This provides us with an opportunity to answer two interesting questions. First what is the driving force behind the increase in the relative value of the S\&P 500 index in the recent years. The S\&P index has outperformed broader stock indexes, recently causing analysts to question whether this is due to fundamental differences in index composition, or to investor preference for the index itself. We give evidence to support the investor preference hypothesis. Second, we can test a long-standing tenet of the financial microstructure literature, that demand shocks due to liquidity trading are temporary and tend to mean revert over time. In particular, in their paper Campbell, Grossman and Wang (1992) show that assets react to information shocks over time in a different way, according to the nature of the shocks. Prices mean-revert if the information shock is transitory and idiosyncratic. No mean reversion takes place if the public flow of information is about permanent news. Usually idiosyncratic shocks are loosely identified with "liquidity trading", while permanent shocks are traced back to more systematic structural factors (e.g. dividends or earning announcements). However a formal test to identify permanent vs. temporary shocks is difficult to perform. Our dataset provides us with the opportunity to test this important issue. We examine shocks to prices originated by demand flows into index funds (typically "liquidity trading" types of shocks). If they are temporary, then we expect them to revert overnight or in the following days, resulting in a negative correlation between flows and 
future returns. If the shocks are permanent they should be incorporated into prices and no reversion or lagged relation in returns should exist. To further examine this effect, we also consider the related behavior of the S\&P futures index. The question of whether liquidity shocks are transitory is a fascinating one. If the recent growth in the S\&P has been entirely due to uninformed inflows, this lends support to the Bakshi and Chen (1994) and Constantinides, Donaldson and Mehra (1998) thesis about the changing equity premium, as well as revealing the mechanism of the change.

Finally, what influences demand? Research by Cohen (1998) suggests that individuals have a tendency towards positive-feedback trading, but other factors beyond past price dynamics may affect demand. Both Cohen (1997) and Zheng (1997) find evidence that bond yields affect equity purchase and sale decisions. Recent empirical studies by Sirri and Tufano (1993) and Chevalier and Ellison (1995), carried out with low frequency (quarterly) data and using net inflows ${ }^{3}$ in the funds, show that investors seem to react non-linearly to fund performance, asymmetrically flocking in when performances have been high and staying in after bad performance. These results seem to suggest performance-chasing behavior by investors and low risk aversion. In this paper, we will show that, at higher frequency (daily) and breaking down flows into inflows and outflows, the behavior for investors in index funds turns out being completely different. It appears that only investors' outflows are affected by past performance, while inflows are not. Also, the investors' behavior appears to be mainly motivated by risk aversion, instead of return-chasing ${ }^{4}$.

\footnotetext{
${ }^{3}$ Given that a separate breakdown into inflows and outflows is not available for mutual funds, such authors construct flows as "the proportional growth in total assets under management for the fund "in the considered period.

${ }^{4} \mathrm{An}$ alternative hypothesis is that if the investor has constant relative risk aversion and wishes to maintain constant proportion of risky/riskless assets, he will sell equity when its value rises. In this case we would expect a negative relationship between assets demand and asset returns.
} 
Furthermore, among the different potential motivating factors we focus on expert recommendations. Using the average market-timing newsletter recommendation over the period, we find that investors appear to react to expert advice about the market. Bullish newsletter sentiment is associated with greater inflows and smaller outflows, but, again, more than by the average recommendation, investors seem mostly influenced by uncertainty. Indeed, dispersions of analysts' opinions reduce inflows and increase outflows.

\section{Data Description}

\section{II.1 Funds}

Our study focuses on three Fidelity index funds: the Spartan U.S. Equity Index ( $\$ 12.9$ Billion), the Spartan Market Index (\$5.8 Billion) and the VIP Market Index ( $\$ 3.0$ billion) over the period 1993 to the present. We have daily dollar-valued share purchases and share redemptions for each of the three funds, as well as their daily returns. Together, the three funds represent approximately $20 \%$ of the mutual fund money indexed to the S\&P 500 -- while they are not as large as the Vanguard Market Index Trust (\$64 Billion) their assets are considerable. The Spartan U.S. Equity Index is a no-load fund, the Spartan Market Index has a 1/2 \% charge for redemption within 90 days and the VIP Market Index is sold principally through insurance channels. Also there is a strong difference between the two Spartan indexes in terms of minimum initial investment that is equal to 10,000 Dollars for the Spartan market Index (1/2\% load fund) and equal to 100,000 Dollars for the Spartan U.S. equity Index (no-load fund). The difference in initial investment provides a way of testing investors' behavior according to their wealth. We expect that, in general, richer investors will have a lower sensitivity to short term market swings 
either because their sensitivity to risk is lower ${ }^{5}$ or because their investment horizon is longer, or because they are better informed on long run trends. This effect should overcome the one due to the absence of back-end fee traditionally considered in the literature (Chordia (1996)). And Indeed, we find that outflows are not sensitive to returns in the fund with the highest investment requirement (Spartan U.S. Equity Index)

There are no precise numbers for how much mutual fund money is indexed to the S\&P 500 , but it is probably between $\$ 80$ to $\$ 100$ billion as of mid-1998. ${ }^{6}$ The Spartan U.S. Equity index is the second-largest S\&P index fund, and The capitalization of the S\&P in mid-1998 was about $\$ 8,900$ billion and so the Fidelity funds hold no more than about $1 / 4$ of a percent of the total capitalization of the S\&P portfolio. Never-the-less, they may represent the marginal investors in S\&P 500 stocks - only a small portion of shares of stocks in the S\&P 500 (1/4 percent) turn over each day. ${ }^{7}$ The correlation in investor flows across the Fidelity funds is high suggesting that the timing of inflows and outflows of these funds is likely to be representative of the other index mutual funds.

Even if the investors in our sample were perfectly representative of the investors in other index mutual funds, they represent only a fraction of the equity indexed to the S\&P. A substantial portion of institutional money is indexed. To the extent that institutional managers

\footnotetext{
${ }_{6}^{5}$ This can be explained if investors have CARA utility function.

6 This estimate is based upon a list of 19 index funds managing $\$ 78$ billion as of May, 1998, listed by Index Funds Online (http://www.indexfundsonline.com/reports/qtr982c0.html). This is certainly an underestimate, since only one of the three funds in our sample is included in the list. Of the 19 funds, Fidelity Spartan Market Index Trust is the second largest, behind the Vanguard Market Index Trust. CNNfn estimated in June 1997 that 59 S\&P Index funds managed $\$ 83$ billion in assets (http://europe.cnnfn.com/yourmoney/9706/24/yomo_indexfunds/).

${ }^{7}$ No daily turnover information for the S\&P 500 stocks is available, but dollar-valued turnover information about the NYSE is probably fairly representative since S\&P 500 stocks represent most of the capitalization of the NYSE (more than $90 \%)$.

NYSE capitalization as of 6/98 was $\$ 9,900$ billion and trading activity for the first six months of 1998 was $\$ 3,474$ billion, suggesting $60 \%$ of share transacted per year, or about $1 / 4$ percent. Thus the daily volume of the S\&P 500
} 
behave differently from individual investors, we might expect the flows to mutual funds to be only partly correlated to flows by institutions. Thus, we expect to find modest price effects conditional upon fund flows. Share purchases, due to automatic dividend re-investment, are treated separately. There is a strong increasing trend in the flows for each of the funds through time. This trend is undoubtedly due to both the growing popularity of indexing as well as the efforts by Fidelity to attract customers. It may also simply reflect increasing demand for mutual funds in general and for equities in particular. Although this is an interesting issue, in this paper we are concerned with very short-term shifts in demand. Thus, it is important to control for these long-term effects. In the analysis below, we normalize the flows to account for both market growth and fund growth. Market growth is important since the total capitalization of the S\&P 500 grows over the interval of study. A $\$ 100$ million demand shock in the early part of the sample period cannot be equated with a $\$ 100$ million demand shock in the later part of the period, given that the S\&P has averaged more than $20 \%$ return in the period.

Simply dividing by the capitalization, however, does not account for the fact that we are using the funds as proxies for daily demand shocks by other index fund customers. While Fidelity's index funds are not as large as Vanguard's Market Index Trust, particularly early in the sample, we expect their flows to have been correlated, and thus to provide us information about what index customers behavior in general. Thus we also normalize by dividing standardized flows by their 180-day moving average. In effect, we examine the behavior of local deviations in inflows and outflows expressed as percentage "market share."

must currently be over $\$ 20$ billion. While volume cannot be equated exactly with the percentage of the company that 


\section{II.2 Stock market variables: $S \& P 500$ and $S \& P 400$ spot and futures}

We consider both the spot and futures total return on the two indexes, the S\&P500 and the S\&P400. The stocks that compose the S\&P400 basket are approximately the next 400 biggest after those represented in the S\&P500. Although not formally tested in this paper, we expect them to be subject to the same type of systematic shocks and, on average, to react to them similarly due to similar betas ${ }^{8}$.

We treat futures and spot prices as contemporaneous end-of-day observations, however as Miller, Muthuswamy and Whaley (1994) point out, this may not be a well-founded assumption, due to non-trading or delayed trading in the spot. They suggest that the reversion in the futures basis may be due not to arbitrage, but rather to stable spot prices. To address this, we separate the basis into the spot and futures prices and find evidence consistent with their assertion that daily basis reversion is not arbitrage-related.

We also consider the total volume of transactions in the S\&P500 index, the open interest on the futures, the market capitalization and the implied volatility. In particular, implied volatility is calculated as the volatility on the S\&P500 index derived by the options on the S\&P futures. Call options at the money for the shortest maturity period are used. Both open interest and implied volatility can be defined either as measures of investors' uncertainty or as measures of dispersion of beliefs. Open interest, in particular, has been identified with dispersion of beliefs. We will show how our analysis can lead to a reformulation of such a definition. In particular we will show that investors react more strongly to risk than to expected return. This is

changes hands in a given period, it does indicate the order of magnitude.

${ }^{8}$ The fact that we consider indexes helps us as it eliminates most of the idiosyncratic effects specific to any stock. (We thank R. Shiller for helpful discussion on this point). 
consistent with recent results (Busse (1997)) that, using a frequency of data analogous to ours (daily), show how mutual fund managers' exploit this feature explicitly timing volatility ${ }^{9}$.

\section{II.3 Market- Timing Newsletter Data}

Forbes columnist Mark Hulbert provided us with a dataset compiled by the Hulbert Financial Digest covering 101 investment newsletter during the period June 1980-December 1997. This database has been studied carefully in Harvey and Graham (1996). They find no evidence of market-timing ability by managers but Graham (1998) finds some evidence that newsletters herd in their recommendations. This database allows us to address the issue of how analysts' reports affect financial markets. The "recommendations" contained in the dataset are defined as a proposed portfolio composition, expressed as a percentage of stocks vs. t-bills to be held in the portfolio. The average recommendation changes daily, although most newsletters are published weekly or at longer intervals. Thus, even though all newsletter publishers may have changed their opinions at once on a given day, it takes about a week for these opinion changes to find their way to print. At, the same time, the dataset has been constructed in such a way that each new observation is "added to the raw file the date Hulbert receives it in the mail or over the phone for letters with free hotlines, rather than the date published on the newsletter". This should properly account for the time it takes to reach the investors. To allow for additional delay in the time it takes to reach investors (on top of the time already allowed for to reach Hulbert), we considered the average value of the recommendations at $\mathrm{t}$ and $\mathrm{t}-1$.

\footnotetext{
${ }^{9}$ In particular, using daily data, Busse shows that volatility timing is an important factor in the return generating process of the fund industry as a whole, leading to varying degrees for individual funds and significantly contributes to traditional fund performance estimates.
} 
We use the sub-sample covering the period January 1993-December 1997 and construct the average recommendations by the newsletters as well as the cross sectional standard deviation. Given that the distributions are skewed and the mean may not be the correct locational measure to use, we also use the median recommendation.

\section{Tests and Results}

The first goal is to test if fund inflows move the index or if changes in the index determine investors' flows or both. To this purpose, we regress the S\&P500 returns on funds' flows. In addition, we reverse the regressions and examine the response of flows to lagged S\&P 500 returns. In addition we run an explicit test of causality to test the direction of causality. Next, we explore the potential motivation for trading by regressing inflows and outflows on the newsletter recommendation series. Finally, we consider the extent to which the S\&P price changes due to demand shocks are permanent or temporary by using the changes in the S\&P 500 futures prices in place of spot and by considering whether price reversals in the basis are due principally to the spot reversing or the future reversing. The logic of using the futures price is that it represents a future claim on the $\mathrm{S} \& \mathrm{P}$. If changes are expected to revert before the exercise date, then the futures price will not react to dynamics due to demand. All the specifications have been estimated using a Cochrane-Orcutt correction for autocorrelation. Also, to check the robustness of our estimations, all the functional specifications have been re-estimated using a White-correction for the errors to control for heteroskedasticity and autocorrelation.

We checked if flows and returns are unstationary, using Dickey-Fuller tests for unit roots. The tests reject at $99 \%$ confidence the existence of unit roots for all the considered series. 


\section{III.1 Spot Returns on Flows}

We are interested in seeing if there is any relationship between each fund's flows and market returns. To pursue this goal we look at both the relationship between funds' flows and the S\&P500 return, and the one between flows and the difference between S\&P500 returns and S\&P400 returns. The implied assumption is that if there is any strong underlying relationship between funds' flows and asset returns, it should manifest itself mostly on the stocks composing the index and not on the other stocks. We therefore conduct a set of linear regressions of both S\&P 500 returns and of the difference between S\&P 500 and S\&P 400 returns on normalized contemporaneous inflows and outflows from each of the three funds. The specification of this test is straightforward. Since the fund flows are only proxies for index fund flows in general, we do not allow for time-variation in coefficients due to changes in fund size. We estimate the equations:

$$
R_{t}=\alpha+\beta * I_{t}+\varepsilon_{t}
$$

and

$$
R_{t}=\alpha+\beta * O_{t}+\varepsilon_{t}
$$

where $\mathrm{R}$ is the daily return on the $\mathrm{S} \& \mathrm{P}$, while $\mathrm{I}$ and $\mathrm{O}$ represent normalized daily fund inflows and outflows respectively. We start simply, focusing on the contemporaneous relationships, even if it is conceivable there is some complex, lagged structural relationship among returns and flows that would demand a more sophisticated specification.

Tables 3-4 show the results of the first set of regressions of S\&P 500 returns on fund inflows and outflows. For consistency with Warther (1995) we report results for the flows normalized by the trailing 160 -day moving average of the S\&P 500 capitalization. To test for the robustness of the results to the type of standardization technique used, we re-estimated all the 
functional specifications using a different standardization procedure based on the daily "innovation" component of the flows. In particular, we used the following standardization procedure:

$$
\text { SFlows }=\frac{\text { RFlows }}{\text { RMAMKT }}-\frac{\text { MAFlows }}{\text { RMAMKT }}
$$

where SFlows are standardized flows, RFlows are the "raw" flows, before standardization,

MAMKT is the rolling moving average of market capitalization in the previous 160 days and

MAFlows is the moving average of the flows in the previous 160 days.

Given that the results agree, we report only one specification. Each fund is reported separately.

While the explanatory power of the regressions is modest ${ }^{10}$, the results are consistent across

funds -- the coefficient on contemporaneous flows is positive and significant at the $5 \%$ level. The results show a positive correlation between inflows and returns and a negative one between outflows and returns.

The results for the specification where the difference between S\&P 500 and S\&P 400 returns and funds' flows agree with the previous ones, showing a positive relationship between inflows and returns differentials between S\&P500 and S\&P400 index returns and a negative one between them and outflows (Tables 22 and 23). We will come back more in depth in the end of the paper.

\footnotetext{
${ }^{10}$ The low explanatory power of the regressions, both when regressing market returns on flows and when regressing flows on past returns is due to the limited sample available. It is hard to expect that the behavior of a single fund could affect the market index, explaining a large portion of its variation. This is confirmed by the fact that, running the same regressions on the aggregate flows of the three funds added together, the explanatory power rises. On the other hand, in terms of explaining funds inflows with market returns, there are idiosyncratic effects that get washed out once more funds are pooled together. We report the disaggregated results because they provide an interesting view on how investors' heterogeneity (captured by differences in minimum investment requirements among funds) affect their investment behavior.
} 
To test the direction of causality more formally, we run a Geweke-Meese-Dent (1983) test of causality, using market returns and flows into the funds. The results are represented in Table 5. This test is robust to autocorrelation and to misspecification in the determination of the correct number of lags ${ }^{11}$. Both types of specifications reject the null of no-causality from flows to market returns, while fail to reject the null of no-causality in the other direction (from market returns to funds' inflows).

Of interest in is the lack of significance for the outflows on the second fund. This is the fund with a minimum initial investment requirement equal to 100,000 dollars. We expect that the investors in such a fund are more "sophisticated" and wealthier. This should reduce their sensitivity to market short-term swings and, therefore, the sensitivity of outflows to market negative returns.

These results are consistent with Warther's evidence using aggregate flows at the monthly level for all mutual funds. With the benefit of daily data, however, we can reject the hypothesis that investors are simply chasing the market intra-day.

One approach to measuring the effects of demand shocks is based on the assumption that positive feedback trading, if it exists, cannot be solely confined to one day -- feedback trading must also happen on the day following a big market move, if it occurred contemporaneously. To see if we can reject positive feedback trading at daily intervals, we next regress flows on lagged returns.

\section{2 Futures Returns on Flows}

\footnotetext{
${ }^{11}$ We consider both the S\&P500 returns and the difference between S\&P500 and S\&P400, as well as the aggregate flows for the three funds
} 
When new money flows in, the fund manager can either buy stocks or take a long position in the futures market. In the former case, this could drive up futures prices. Given the low transaction costs and high liquidity of the futures market and the possibility of higher leverage that such a market offers, it is likely that this can be a preferred direction of investment for fund managers. Therefore, analogous to what we did for the spot market, we regress futures returns on contemporaneous inflows and outflows, according to:

$$
R_{t}=\alpha+\beta * I_{t}+\varepsilon_{t}
$$

in the case of the inflows, and

$$
R_{t}=\alpha+\beta * O_{t}+\varepsilon_{t}
$$

in the case of the outflows. We consider the returns on the futures on the S\&P500, the difference between such futures and the spot index S\&P500 and the difference between the futures on the S\&P500 and the futures on the S\&P400 ${ }^{12}$. As with the spot price, all the regressions are significant, showing a positive correlation between inflows and futures returns and a negative one between outflows and futures returns. This tells us that the two markets are linked-either by fund manager activity or by arbitrage across them.

We report the key results in Tables 6-7. In particular three results are worth mentioning. First, the data tell us that fund managers may invest at least part of their new money in the futures markets taking long positions. But the behavior in the futures markets changes according to the nature of the flow. New inflows appear to affect first the futures market. Therefore the return differential between futures and spot market is positively correlated to inflows. Outflows, on the contrary, appear to induce the managers to first liquidate their spot positions. This induces a positive correlation between outflows and the futures-spot return differentials. In terms of 
differential with respect to the S\&P400 futures, the results are more uncertain. They are significant only if we consider the total inflows aggregated and not, as we have done up to now, fund by fund. In this case they show a positive relationship between inflows and returns differential between S\&P500 and S\&P400.

\section{III.3 Flows on Returns}

To investigate the effects of past returns on the decision to invest in funds, we consider two specifications. The first is a regression of inflows (outflows) on contemporaneous returns and past (one-period lagged) inflows (outflows). The second is a regression of inflows (outflows) on multiple lagged returns and inflows (outflows).

The first specification is given by:

$$
I_{t}=\alpha+\beta * R_{t}+\gamma * I_{t-1}+\varepsilon_{t}
$$

for the inflows and:

$$
O_{t}=\alpha+\beta * R_{t}+\gamma * O_{t-1}+\varepsilon_{t}
$$

for the outflows. Lagged flows are used to control for trend. Two specifications are considered: one with returns on the S\&P 500 index and one with the difference between these returns and those on the S\&P 400 index. Given that the results agree we report and describe the former, referring to the last section of the paper for a proper description of the latter.

In the second specification, we test the lagged influence of returns on flows, estimating the following equations:

$$
I_{t}=\alpha+\sum_{k=0}^{N} \beta_{k} * R_{t-k}+\sum_{k=1}^{N} \delta_{k} * I_{t-k} \varepsilon_{t}
$$

\footnotetext{
${ }^{12}$ See note 6.
} 
for the inflows and

$$
O_{t}=\alpha+\sum_{k=0}^{N} \beta_{k} * R_{t-k}+\sum_{k=1}^{N} \delta_{k} * O_{t-k} \varepsilon_{t}
$$

for the outflows. Here $\mathrm{N}$ represents the number of days we included in the regression. To keep the specification parsimonious and, at the same time, to include the salient lags, we consider six lags $(\mathrm{N}=5)$. This covers the full trading week and picks up the returns of the last day of the previous week.

The results of the regression of flows on S\&P500 returns are reported in Tables 8 and 9 13. They show a strong positive correlation of inflows on contemporaneous returns and a negative one between outflows and contemporaneous returns. This specification confirms the results of the previous sections. It also allows us to better control for trends in the flows by explicitly modeling the temporal dependence by adding of the lagged dependent variable. Analogous results are reported for the relationship between funds' flows and futures market returns (not reported in the tables).

Results for lagged returns are reported in Tables 10 and 11 for the spot market case and in Tables 12 and 13 for the futures market case. Notice that lack of explanatory power of the regression and the absence of significance for the explanatory variables rule out any causal relationship from past returns to funds' inflows. The behavior of the inflows for all the three funds suggest that when investors decide to invest, they do not chase the trend. In the case of the outflows, on the contrary, a relationship seems to exist for the first and third fund, while no relationship is detectable for the second fund. This is justifiable in term of its peculiar fee 
structure. The existence of a statistically significant relationship between outflows and past returns and the lack of any relationship between these and inflows, seems to suggest an asymmetric behavior by investors who react more quickly to bad than to good news.

It is interesting to note that lagged net inflows (not reported in the tables) are never significant, either considering the three funds separately, or aggregating the data ${ }^{14}$. This should sound as a warning towards that part of the literature that, lacking a separate availability of data on inflows and outflows, has relied on net flows and point toward the need to separately analyze inflows and outflows.

In general the results seem to suggest the lack of sophisticated trend-chasing strategies by the investors, and the existence of a certain degree of over-reaction by risk-averse investors to bad news. It is worth noticing that these results contrast with the results found in studies with lower frequencies (quarterly) where it seems that investors react more to positive returns that to negative ones. Also, using daily data, we thus confirm Warther's hypothesis that feedback trading is not driving the relationship between monthly flows and returns (at least for the case of inflows). The higher frequency data allow us to clearly pin down the direction of causality, from inflows to market returns and not vice-versa. The results on the funds' flows-futures returns in a following section strongly confirms this hypothesis, and suggests that the effect of fund share purchases and sales is upon the spot as well as the futures market.

\section{III.4 Explaining Fund Flows}

\footnotetext{
${ }^{13}$ We tested for the robustness of the estimations, using different standardizations of the flows. As the results agree we do not report them, but are available upon requests from the authors.

${ }^{14}$ This fits with the previous results that, for the tests of Granger causality find a more significant relationship for the outflows than for the inflows.
} 
Although we find no support for positive feedback trading, the general question of what motivates the flows in and out of index funds is an important one. We would expect that most of the inflows and outflows are the result of liquidity trading by uninformed investors. We examined the data for evidence of seasonality at the monthly and daily levels to see if inflows occurred at regular intervals. We expected, for example, that end of year and beginning of month inflows would be stronger due to deposit of paychecks and bonuses. We do not report the results of this because we found virtually no seasonal variation in flows. The only evidence of seasonality we found was in the strength of the coefficients in the regressions themselves. Flows responded more strongly in January, as well as on Mondays, for example. We do not know why.

\section{III.5 Risk and Uncertainty}

The analysis so far has mainly focused on the first moment of returns. We have shown, that, unlike previous literature assumed, people react more to negative than to positive performance, suggesting that investors' behavior is strongly driven by risk aversion. We now go more in depth into this aspect of investors' behavior, looking directly at how investors' behavior is affected by risk. In particular, we will focus on investors' reaction to risk. We will also look at how expert opinion (i.e. analysts' reports) affect investors' behavior: the results indicate that, even in this case, the second moment (i.e.: volatility and dispersion of beliefs) affect investors more than average returns.

Volatility is a natural variable to use to explain flows, since we expect risk to influence investor portfolio choice. Not only do we have current volatility to use as an explanatory variable for flows, but we also have measures of future volatility. In addition to risk measures per se we also have measures correlated to "disagreement" among participants in the financial 
markets. In particular, the traditional financial microstructure literature usually identifies dispersion of beliefs with open interest and risk with implied volatility. Our analysis offers us the opportunity to reconsider such identification.

We therefore look at the relationship between flows and implied volatility and open interest on the futures on the index. To control for spurious correlation, open interest is considered both before and after standardization by the mean value of the market capitalization. In particular, we test:

$$
I_{t}=\alpha+\beta * R_{t}+\gamma * I_{t-1}+\delta O I_{t}+\varepsilon_{t}
$$

and

$$
O_{t}=\alpha+\beta * R_{t}+\gamma * O_{t-1}+\delta * O I_{t}+\varepsilon
$$

where OI represents the open interest on futures on the S\&P 500.

Beyond checking the robustness of earlier results the objective of this test to see how the decision to invest in index funds is affected by the global level of uncertainty prevailing in the market. For this second purpose we also use the implied volatility, estimating directly:

$$
I_{t}=\alpha+\beta * I_{t-1}+\gamma * I V_{t}+\varepsilon_{t}
$$

and

$$
O_{t}=\alpha+\beta * O_{t-1}+\gamma I V_{t}+\varepsilon_{t}
$$

In this case the implied volatility (IV) directly proxies for the level of market uncertainty and riskiness. Tables 14-17 report the results of the regressions of flows on contemporaneous open interest (Tables 14 and 15) and implied volatility (Tables 16 and 17) of the S\&P 500 index. The coefficients on implied volatility are always highly significant and positive, for both inflows and outflows. A Granger causality test between flows and volume and volatility, (not reported in 
the table) indicate a two-way-causality between them. This would fit with the intuition that future market risk, as well as dispersion in current beliefs, accentuate the index fund flows. On the contrary, open interest affects only outflows. Also, although not reported, the added absolute values of daily inflows and outflows are strongly correlated to volume, volatility and open interest.

These results seem to suggest that open interest could be a good proxy of market riskiness, while implied volatility would proxy for dispersion of beliefs. Indeed, higher riskiness should affect outflows, with a negative or zero effect on inflows, while dispersion of beliefs should increase both inflows and outflows, as it increases both the people who flock in the market under the expectation of higher returns and the people who leave it, fearing lower returns. And this is indeed what the results suggest.

We will see later how dispersion in the beliefs of the financial analysts, again play a stronger role than their average recommendations. All this seems to portray a clear picture of investors' risk aversion, very different from the one traditionally observed at lower frequency.

\section{III.6 Market timing newsletters}

Next, we look at the relationship between market timing newsletters and investment flows into the funds. Some fund flow is likely due to speculative trading as opposed to liquidity trading. What information do these speculators use? We consider a number of potential information sources for speculative trading: macro-economic data and expert recommendations.

Although Graham and Harvey (1996) found little evidence that these newsletters as a whole had any timing ability, they never the less appear to generate self-sustaining profits 
through subscriptions. In order to determine the influence of expert opinion on the inflows and outflows, first we regress flows on the mean value of recommendations:

$$
F_{t}=\alpha+M R_{t}+\operatorname{Info} o_{t}+\varepsilon_{t}
$$

and on their cross-sectional dispersion:

$$
F_{t}=\alpha+S R_{t}+\operatorname{Info} o_{t}+\varepsilon_{t}
$$

Here MR and SR are, respectively, the mean value of the recommendations and their dispersion (calculated as standard deviation) ${ }^{15}$. Both the specifications are tested alone and including additional "information variables" (Info). These variables have been widely used in the literature. In particular, a number of papers have pointed out that macroeconomic variables may help explain variations in the equity premium in the short run. Ferson and Schadt (1995) point out that performance evaluation of fund managers should take into account the value of conditioning on macroeconomic conditioning. Graham and Harvey (1996) explicitly test the timing ability of newsletters by conditioning upon macroeconomic variables. We use these variables to control for other additional sources of information investors can base their behavior on. The natural candidates we consider are the 3-month interest rate, the quality spread, the term spread between long and short term bonds and the dividend yield. It is a very strong test of the impact of the newsletters, as additional explanatory power would imply an information set not directly contained in that of the other existing variables and, therefore, superior capacity as leading indicator. The average of the contemporaneous and lagged mean value is used to capture effects due to the lagged arrival of reports. ${ }^{16}$

\footnotetext{
15 As mentioned before, to properly account for the time it takes to reach the investors, both MR and SR are calculated as the average between the values at time $t$ and $t-1$.

16 Alternatively, we also estimated the same regressions the median value. Given that the results for the mean and median recommendations coincide we will refer only to those using the mean.
} 
The results are reported in Tables 18 and 19 for the average investors' recommendations and in Tables 20 and 21 for the dispersion of analysts' beliefs. They show that recommendations to invest into stocks increase inflows into index funds, reducing outflows. The results are strongly more significant for the outflows (except for the second fund for which the specific type of exit fee affects the results). The inflows are significant only for the first fund.

Interestingly, the flows seem to be more strongly affected by the dispersion of opinion among analysts, than by their average recommendations. In particular a higher dispersion of newsletter opinions lowers the inflows and increases the outflows. This confirms the earlier results that risk averse investors tend to react more to uncertainty and risk and less according to a return-chasing behavior.

In general, analysis of the investment timing newsletter recommendation seems to suggest that the markets follow analysts' suggestions, increasing the investment into the funds and reducing their divestments from them, whenever analysts' reports "agree" on suggesting to invest into stocks.

\section{III.7 Permanent or Temporary Price Effects?}

An important issue is whether these uninformed investor demand shocks are temporary or permanent and if temporary, can they be arbitraged by program traders. S\&P index funds in general promise investors end-of-day pricing. That is, they promise investors that share redemptions and purchases will be executed at same-day closing prices. We expect that the funds thus minimize tracking error by entering market on close orders for the net dollar value of their flows. By its very nature, however, a market-on-close price is not arbitrageable against the 
futures market. The question is how this change of the market-on-close price will affect future prices, that is, if it will revert the following day.

Prices are assumed to mean-revert if the information shock is a transitory idiosyncratic shock, while no mean reversion takes place if the public flow of information is about permanent news. Using flows and returns we can test if the idiosyncratic demand shocks due to funds' flows are permanent or temporary or permanent. If they are temporary, we expect them to revert over night or in the following days, originating a negative correlation between flows and future returns. If the shocks are, instead, permanent they should be incorporated into prices and no correlation should be found in the following days. To test this hypothesis we looked at the relations between funds' flows and index returns. In particular, we run the following regressions:

$$
R_{t}=\alpha+\sum_{k=0}^{N} \beta_{k} * R_{t-k}+\sum_{k=0}^{N} \delta_{k} * I_{t-k} \varepsilon_{t}
$$

and

$$
R_{t}=\alpha+\sum_{k=0}^{N} \beta_{k} * R_{t-k}+\sum_{k=0}^{N} \delta_{k} * O_{t-k} \varepsilon_{t}
$$

where $\mathrm{R}$ are the percentage daily returns on the S\&P 500, both spot and futures.

For our experiments we consider three intervals: the interval market opening-to-market closing, the interval closing of the previous day-closing of the following day, the interval between market closing of the previous day and market opening of the following day. Then we consider the relationship between flows and market returns for the successive $\mathrm{N}$ days, where $\mathrm{N}$ is assumed to be equal to 5, to consider all the weekly effects. The rationale behind these tests is the idea that if there is mean reversion in returns, we would expect to find correlation between past flows and returns. If, on the contrary, the demand shocks are permanent, no correlation is 
expected between past flows and returns. Therefore, testing the null hypothesis of no-mean reversion is equivalent to testing the hypothesis that all the $\delta$ s are equal to zero or not significant.

The results (not reported as all of them not statistically significant) hold for all the different specifications, with both spot returns, futures returns and fail to reject the null hypothesis of no-mean reversion. In particular, they show a strong contemporaneous relationship between flows and returns, and no relationship at all between flows and future returns.

The lack of correlation between the overnight price change and the flows in the previous day and between then flows and returns in the following and the other consecutive days (not reported in the tables) seem to confirm the hypothesis that the shocks due to funds inflows are not temporary, but are permanent. This test of market reaction to liquidity trading seems to rejects the long-standing tenet that liquidity trading shocks mean revert and are temporary.

One possible implication of the permanent nature of demand shocks is that the growth of the stock market during the last period of study may, in part, be a product of demand, not economic fundamentals like dividend yields. To further analyze this issue, we look at the relationship between the S\&P500 and the S\&P400 index. If index funds played any role, we would expect that the difference in stock market growth between S\&P500 and S\&P400 be affected by the behavior of the S\&p500 index funds.

As a first preliminary test, we looked at the size and significance of the coefficients representing the impact of flows in index funds on the S\&P500 index, calculated with rolling regressions, over 600 day moving windows. Figure 1 reports the point values of the coefficients, as well as their estimated standard deviations. The increasing significance, as well as size of the impact of fund flows is striking and can be due to the growing absolute size of the index fund industry as well as to it increasing more important relative role. 
In Figure 2 and 3 three indexes have been considered: S\&P400 and S\&P500 and a new index that has been constructed deducting from the S\&P500 index the part of it growth due to the impact of the net (inflows net of outflows) index funds. The new index has been constructed calculating the impact of the net flows in index funds in the index, through a regression over the entire sample period (Figure 2) and through a series of rolling regressions of the index returns on funds' flows and using the estimated coefficients to calculate the part of the returns due to the impact of funds' flows (Figure 3). The resulting index has been constructed taking out the cumulated component due to the funds. The figure is striking: a large portion of the spread between the two indexes may be due to net demand shocks.

To test for the significance of the results, we run a series of bootstrapping experiments. For the coefficient measuring the impact of fund flows on the S\&P500 calculated on the entire period (Figure 2) and for each coefficient calculated for each single rolling regressions (Figure 3), we calculated confidence bands bootstrapped 5,000 times and constructing 95\% intervals around the estimated coefficients. Using these as new coefficients, we then calculated the bands for the new constructed index (the so called "S\&P500 net of fund effects"). The bands are reported as "Upper Band" and "Lower Band". The relatively narrow dimension of the bands with respects to the difference between the new constructed index and the S\&P ones, allows us to reject the hypothesis that the net effect on demand on market price level is zero.

In short, the important role played by the index funds is shown not only by the huge difference $(-36 \%)$ between the two indexes that can be explained in terms of funds' flows (Figures 2 and 3), but also by the increasing significance of the explanatory power of the coefficients of funds' flows on the index over time (Figure 1). This striking growth of 
explanatory power coincides with both the fast growth of the stock index and the development of the index fund industry and the growth in size of the three funds we considered.

To test this hypothesis more rigorously, we estimated the following specifications:

$$
\begin{aligned}
& S R_{t}=\alpha+\sum_{k=0}^{N} \beta_{k} * N F_{t-k}+\varepsilon_{t} \\
& F R_{t}=\alpha+\sum_{k=0}^{N} \beta_{k} * N F_{t-k}+\varepsilon_{t}
\end{aligned}
$$

We considered alternative specifications, where SR is the difference between the returns on the S\&P500 spot and the returns on the S\&P400 spot index and FR is the difference between the return on the S\&P500 futures and the S\&P400 futures index. Given that we are looking for a direct effect of investment in index funds on market returns, we consider the net flows (NF ia given by Inflows minus Outflows). In Tables 22 and 23 are reported the results of the effects of flows on the S\&P500-S\&P400 spot and futures spread. The results confirm the intuition that the spread between S\&P500 and S\&P400, both spot and futures is strongly influenced by flows in index funds. The more money flows into index funds, the more these influence market returns increasing the value of the stocks part of the S\&P500 basket.

\section{Conclusions}

Our analysis of high frequency flow of funds data for a set of large S\&P 500 index funds strongly suggests that investor demand influences stock returns but not vice-versa. Using higherfrequency data and being able to consider both inflows and outflows separately, we show that investors are more affected by risk than by performance. We show that they tend not to chase positive trends in returns, while they over-react to negative returns immediately liquidating their 
positions in the funds. This asymmetric behavior is the inverse of the one traditionally found in the mutual fund industry at lower frequencies and raises interesting questions. In particular, it is worth investigating if the difference in results are due to a structural difference in behavior between mutual fund and index fund investors, suggesting some sort of "clientele" hypothesis to test, or if these results are driven by the higher precision provided by daily data. In the latter case, the whole traditional analysis of investors' behavior has to be at best reformulated.

We also find some other interesting determinants of investor demand, including risk variables and expert recommendations. An analysis of the dynamics of the S\&P 500 futures basis suggests that the variations due to demand shocks are largely permanent. Also, the analysis of the effects of funds' flows on the difference in behavior between the S\&P500 and the S\&P400 indexes, both spot and futures sheds some light on the driving force behind the strong growth experienced by the stock exchange during the last decade. 


\section{References}

(1) Bakshi, G. S. and C. Zhiwu , 1994, "Baby Boom, Population Aging and Capital Markets", Journal of Business 67, 165-201.

(2) Beneish, M.D. and R. Whaley, 1996, "An Anatomy of the 'S\&P Game': The Effects of Changing the Rules", Journal of Finance December, 1909-1930.

(3) Busse, J. 1998, "Volatility Timing in mutual funds: evidence from daily returns", N.Y.U. Stern Business School, Mimeo.

(4) Campbell, J., Grossman, S. and J. Wang., 1992 "Trading volume and serial correlations in stock returns", NBER Working Paper \#4193

(5) Chan, L. and J. Lakonishok, 1995, "The Behavior of Stock Prices Around Institutional Trades", Journal of Finance, 1147-74.

(6) Chan, L. and J. Lakonishok, April 1993, "Institutional Trades and Intraday Stock Price Behavior", Journal of Financial Economics, 33(2), 173-99.

(7) Chevalier, J. and G. Ellison, August 1995, "Risk taking by mutual funds as a response to incentives", NBER Working Paper \#5234.

(8) Chordia T., 1996, "The structure of mutual fund charges" The Journal of Financial Economics, 41: (1) 3-39.

(9) Constantinides, G., J. Donaldson and R. Mahra, 1998, "Junior Can't Borrow: A New Perspective on the Equity Premium Puzzle," NBER Working Paper \#6617

(10) De-Long, J. B., A. Shleifer, L. H. Summers and R. J. Waldmann, June 1990, "Positive Feedback Investment Strategies and Destabilizing Rational Speculation", Journal of Finance, 45(2), 379-395.

(11) Dent, J., Geweke, R. and W. Meese (1983) "Comparing Alternative Tests of Causality in Temporal Systems: Analytic Results and Experimental Evidence "Journal of Econometrics, 21(2), pages 161-94..

(12) Ferson, W. and R. Schadt, 1995, "Measuring Fund Strategy and Performance in Changing Economic Conditions", Journal of Finance

(13) Ferson, W. and V. A. Warther, 1995, "Evaluating Fund Performance in a Dynamic Market", Financial Analysts Journal. 
(14) Fridson, M. S. and Jonsson, J. (1995), " Spread versus Treasuries and the riskiness of highyield bonds", The Journal of Fixed Income, December, 79-88

(15) Garry M. and W. Goetzmann, 1986, "Does de-listing from the S\&P500 affect stock price?", Financial Analysts Journal, 42(2) 64-69.

(16) Graham, J.R and C., R.Harvey (1996) "Market Timing Ability and Volatility Implied in Investment Newsletters' Asset Allocation Recommendations " Journal of Financial Economics, 42(3), 397-421.

(17) Harris, L. and Gurel, 1986, "Price and Volume Effects Associated with Changes in the Standard and Poors 500 List -- New Evidence for the Existence of Price Pressures" Journal of Finance 41: (4) 815-829.

(18) Lakonishok, J. and A. Shleifer, August 1992, “The Impact of Institutional Trading on Stock Prices", Journal of Financial Economics, 32(1), 23-43.

(19) Lakonishok, J., 1991, "Window Dressing by Pension Fund Managers", American Economic Review, 81(2), 227-31.

(20) Lakonishok, J., A. Shleifer, and R. W. Vishny, 1991, "Do Institutional Investors Destabilize Stock Prices? Evidence on Herding and Feedback Trading”, NBER Working Paper: 3846.

(21) Lynch, A. W. and R.R, Mendenhall, 1997, "New evidence on stock price effects associated with changes in the S\&P 500 index", Journal of Business 70: (3) 351-383.

(22) Shiller, R, (1998) “Comment on Vincent Warther, "Has the Rise of Mutual Funds Increased Market Instability?" “ Brooking-Wharton Papers

(23) Shleifer, A., July 1986, Do Demand Curves for Stocks Slope Down?, Journal of Finance, 41(3), 579-590.

(24) Sias, R.W. and Starks, L.T. (1996) "Return Autocorrelation and Institutional Investors", Journal of Financial Economics, 46, 103-31.

(25) Sirri, E. R. and P. Tufano (1993), "Buying and selling mutula funds: flows, performance, fees and service”, Working Paper, Harvard Business School.

(26) Warther, V. A., 1995, Aggregate Mutual Fund Flows and Security returns, Journal of Financial Economics, 39, 209-235.

(27) Whaley, R. E. and Messod, 1996, D. "An Anatomy of the "S\&P Game": The Effects of Changing the Rules", Journal of Finance; 51(5), 1909-30. 
(28) Whaley, R., M.H. Miller and J. Muthuswamy 1994, "Mean Reversion of S\&P 500 Index Basis Changes: Arbitrage-Induced or Statistical Illusion?", Journal of Finance 49, 479-513.

(29) Zheng, L. 1997, "Stock Prices and Investment Cash Flows," Yale School of Management Working Paper, 1997. 
Table 1

Statistics of funds' inflows and outflows

All the observations are daily. For Spartan Market Index and Spartan U.S. Equity Index they cover the period 1/4/93-12/31/97. For V.I.P.Fund, the period is 5/23/94-12/31/97. All the values are expressed in millions.

\begin{tabular}{lccc} 
& Mean & Standard deviation & Median \\
Spartan Market Index Inflows & 2.99 & 4.13 & 1.19 \\
Spartan US Equity Index Inflows & 9.05 & 13.52 & 5.21 \\
V.I.P. Fund Inflows & 2.13 & 2.38 & 1.42 \\
Spartan Market Index Outflows & 1.06 & 1.57 & 0.46 \\
Spartan US Equity Index Outflows & 6.19 & 11.12 & 2.96 \\
V.I.P. Fund Outflows & 0.46 & 1.19 & 0.07 \\
\hline \hline
\end{tabular}

Table 2

Correlation of funds' inflows and outflows

All the observations are daily. For Spartan Market Index and Spartan U.S. Equity Index they cover the period 1/4/93-12/31/97. For V.I.P.Fund, the period is 5/23/94-12/31/97.

\begin{tabular}{lcccccc} 
Spartan Market Index Inflows & 1.00 & 0.33 & 0.73 & -0.54 & -0.19 & -0.23 \\
Spartan US Equity Index Inflows & 0.33 & 1.00 & 0.31 & -0.20 & -0.40 & -0.05 \\
V.I.P. Fund Inflows & 0.73 & 0.31 & 1.00 & -0.44 & -0.16 & -0.16 \\
Spartan Market Index Outflows & -0.54 & -0.20 & -0.44 & 1.00 & 0.26 & 0.52 \\
Spartan US Equity Index Outflows & -0.19 & -0.40 & -0.17 & 0.26 & 1.00 & 0.11 \\
V.I.P. Fund Outflows & -0.23 & -0.05 & -0.16 & 0.52 & 0.11 & 1.00 \\
\hline
\end{tabular}


TABLE 3

Spot market returns and funds' inflows

The functional specification is $R_{t}=\alpha+\gamma$ Inflows $_{t}+\varepsilon_{t}$, where $R_{t}$ is the percentage return on the S\&P 500 spot index and Inflows $\mathrm{s}_{\mathrm{t}}$ are the contemporaneous inflows in the index funds. The inflows are standardized dividing them by the average market capitalization in the previous 160 days. The estimations are White-corrected to control for heteroskedasticity and autocorrelation. All the observations are daily. For Spartan Market Index and Spartan U.S. Equity Index they cover the period 1/4/93-12/31/97. For V.I.P.Fund, the period is 5/23/9412/31/97. A bootstrap of the t-statistics was performed by repeatedly constructing a pseudo-history for the S\&P by randomly drawing from the dependent variable with replacement and re-performing the regression. The probability of observing a $t$-value greater than the magnitude of the observed $t$-value in each regression under this null is less than $1 \%$.

\section{Dependent Variable: S\&P 500 RETURN}

\begin{tabular}{lcccccc}
$\begin{array}{l}\text { Independent } \\
\text { Variables }\end{array}$ & \multicolumn{2}{c}{ Spartan Market Index } & \multicolumn{2}{c}{ Spartan U.S. Equity Index } & \multicolumn{2}{c}{ V.I.P Fund } \\
& Value & T Stat. & Value & T Stat & Value & T. Stat. \\
Constant & 0.0001 & 0.36 & 0.0003 & 1.09 & -0.001 & -1.91 \\
Fund's Inflows & & & & & & \\
Corrected $\mathrm{R}^{2}$ & 0.001 & 2.50 & 0.0002 & 2.36 & 0.004 & 4.10 \\
Durbin Watson & 0.008 & & 0.005 & & 0.05 \\
$\begin{array}{l}\text { Number of } \\
\text { Observations }\end{array}$ & 1.97 & 1.97 & & 1.96 \\
\hline
\end{tabular}

TABLE 4

Spot market returns and funds' outflows:

The functional specification is $R_{t}=\alpha+\gamma$ Outflows $_{t}+\varepsilon_{t}$, where $R_{t}$ is the percentage return on the S\&P 500 spot index and Outflows $\mathrm{s}_{\mathrm{t}}$ are the contemporaneous outflows in the index funds. The outflows are standardized dividing them by the average market capitalization in the previous 160 days. The estimations are White-corrected to control for heteroskedasticity and autocorrelation. All the observations are daily. For Spartan Market Index and Spartan U.S. Equity Index they cover the period 1/4/93-12/31/97. For V.I.P.Fund, the period is 5/23/9412/31/97. A bootstrap of the t-statistics was performed by repeatedly constructing a pseudo-history for the $\mathrm{S} \& \mathrm{P}$ by randomly drawing from the dependent variable with replacement and re-performing the regression. The probability of observing a $t$-value greater than the magnitude of the observed $t$-value in the first and third regression under this null is less than $1 \%$.

Dependent Variable: S\&P 500 RETURN

\begin{tabular}{|c|c|c|c|c|c|c|}
\hline \multirow{2}{*}{$\begin{array}{l}\text { Independent } \\
\text { Variables }\end{array}$} & \multicolumn{2}{|c|}{ Spartan Market Index } & \multicolumn{2}{|c|}{ Spartan U.S. Equity Index } & \multicolumn{2}{|c|}{ VIP Fund } \\
\hline & Value & T Stat. & Value & T Stat & Value & T. Stat. \\
\hline Constant & 0.001 & 5.38 & 0.0008 & 3.62 & 0.002 & 5.95 \\
\hline Fund's Outflows $s_{t}$ & -0.003 & -2.83 & -0.00002 & -0.17 & -0.012 & -3.73 \\
\hline Corrected $\mathrm{R}^{2}$ & 0.01 & & 0 & & 0.10 & \\
\hline Durbin Watson & 1.97 & & 1.96 & & 1.99 & \\
\hline Number of Obs. & 1105 & & 1105 & & 755 & \\
\hline
\end{tabular}


Table 5

Tests of causality of the relationship between

funds' flows and market returns

The causality tests are based on the Geweke-Meese-Dent specification, where the dependent variable is regressed on the lagged dependent variable itself and on the leads, lags and the contemporaneous values of the "exogenous" variable. The test is based on the exclusion of the lead values. The spot market return is the percentage return on the S\&P 500 spot index, while the futures market return is the percentage return on the S\&P 500 futures index. The inflows and the outflows are standardized dividing them by the average market capitalization in the previous 160 days. The estimations are White-corrected to control for heteroskedasticity and autocorrelation. All the observations are daily and the inflows and outflows are calculated adding up the inflows and outflows for the three funds (Spartan Market Index, Spartan U.S. Equity Index and the V.I.P.Fund) .

$$
\text { Number of lags }=6 \quad \text { Number of lags }=12
$$

Direction of causality Chi-square Significance Chi-square Significance

$\begin{array}{lcccc}\text { Inflows cause Spot Returns } & 7.47 & 0.06 & 18.57 & 0.005 \\ \text { Inflows cause Futures Returns } & 16.68 & 0.0008 & 27.83 & 0.0001 \\ \text { Outflows cause Spot Returns } & 0.89 & 0.82 & 4.10 & 0.66 \\ \text { Outflows cause Futures Returns } & 1.16 & 0.76 & 4.61 & 0.59 \\ \text { Spot Returns cause Inflows } & 3.60 & 0.31 & 9.58 & 0.14 \\ \text { Futures Returns cause Inflows } & 4.31 & 0.24 & 8.93 & 0.18 \\ \text { Spot Returns cause Outflows } & 5.62 & 0.13 & 8.59 & 0.20 \\ \text { Futures Returns cause Outflows } & 8.72 & 0.03 & 12.55 & 0.05 \\ \end{array}$


TABLE 6

Futures market returns and funds' inflows:

The functional specification is $R_{t}=\alpha+\gamma$ Inflows $_{t}+\varepsilon_{t}$, where $R_{t}$ is the percentage return on the S\&P 500 futures index and Inflows $s_{t}$ are the contemporaneous inflows in the index funds. The inflows are standardized dividing them by the average market capitalization in the previous 160 days. The estimations are White-corrected to control for heteroskedasticity and autocorrelation. All the observations are daily. For Spartan Market Index and Spartan U.S. Equity Index they cover the period 1/4/93-12/31/97. For V.I.P.Fund, the period is 5/23/94$12 / 31 / 97$

\section{Dependent Variable: S\&P 500 RETURN}

\begin{tabular}{|c|c|c|c|c|c|c|}
\hline \multirow{2}{*}{$\begin{array}{l}\text { Independent } \\
\text { Variables }\end{array}$} & \multicolumn{2}{|c|}{ Spartan Market Index } & \multicolumn{2}{|c|}{ Spartan U.S. Equity Index } & \multicolumn{2}{|c|}{ V.I.P Fund } \\
\hline & Value & T Stat. & Value & T Stat & Value & T. Stat. \\
\hline Constant & -0.00004 & -0.11 & 0.00016 & 0.53 & -0.0016 & -2.12 \\
\hline Fund's Inflows ${ }_{t}$ & 0.0012 & 2.46 & 0.0002 & 2.47 & 0.0055 & 3.92 \\
\hline Corrected $\mathrm{R}^{2}$ & 0.12 & & 0.007 & & 0.054 & \\
\hline Durbin Watson & 2.10 & & 2.10 & & 2.10 & \\
\hline $\begin{array}{l}\text { Number of } \\
\text { Observations }\end{array}$ & 1105 & & 1105 & & 1105 & \\
\hline
\end{tabular}

TABLE 7

Futures market returns and funds' outflows

The functional specification is $R_{t}=\alpha+\gamma$ Outflows $_{t}+\varepsilon_{t}$, where $R_{t}$ is the percentage return on the S\&P 500 futures index and Outflows $s_{t}$ are the contemporaneous inflows in the index funds. The outflows are standardized dividing them by the average market capitalization in the previous 160 days. The estimations are White-corrected to control for heteroskedasticity and autocorrelation. All the observations are daily. For Spartan Market Index and Spartan U.S. Equity Index they cover the period 1/4/93-12/31/97. For V.I.P.Fund, the period is 5/23/9412/31/97.

\section{Dependent Variable: S\&P 500 RETURN}

\begin{tabular}{|c|c|c|c|c|c|c|}
\hline \multirow{2}{*}{$\begin{array}{l}\text { Independent } \\
\text { Variables }\end{array}$} & \multicolumn{2}{|c|}{ Spartan Market Index } & \multicolumn{2}{|c|}{ Spartan U.S. Equity Index } & \multicolumn{2}{|c|}{ VIP Fund } \\
\hline & Value & T Stat. & Value & T Stat & Value & T. Stat. \\
\hline Constant & 0.0012 & 4.31 & 0.0007 & 2.94 & 0.002 & 5.43 \\
\hline Fund's Outflows & -0.0021 & -1.99 & -0.000003 & -0.27 & -0.012 & -3.38 \\
\hline Corrected $\mathrm{R}^{2}$ & 0.003 & & 0 & & 0.07 & \\
\hline Durbin Watson & 2.11 & & 2.10 & & 2.14 & \\
\hline $\begin{array}{l}\text { Number of } \\
\text { Observations }\end{array}$ & 1105 & & 1105 & & 755 & \\
\hline
\end{tabular}


TABLE 8

Funds' inflows and spot market returns:

The functional specification is Inflows $s_{t}=\alpha+\gamma R_{t}+\varepsilon_{t}$, where Inflows $s_{t}$ are the inflows in the index funds at time $t$ and $R_{t}$ is the percentage return on the $S \& P 500$ spot index at t-k. The inflows are standardized dividing them by the average market capitalization in the previous 160 days .To capture all the week effects we considered $\mathrm{k}=5$. The estimations are corrected to control for heteroskedasticity and autocorrelation. All the observations are daily. For Spartan Market Index and Spartan U.S. Equity Index they cover the period 1/4/93-12/31/97. For V.I.P.Fund,

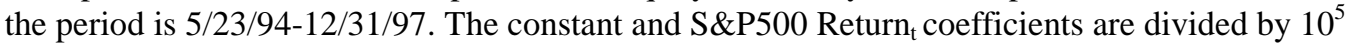

\section{Dependent Variable: Fund's Inflows $s_{t}$}

\begin{tabular}{|c|c|c|c|c|c|c|}
\hline \multirow{2}{*}{$\begin{array}{l}\text { Independent } \\
\text { Variables }\end{array}$} & \multicolumn{2}{|c|}{ Spartan Market Index } & \multicolumn{2}{|c|}{ Spartan U.S. Equity Index } & \multicolumn{2}{|c|}{ V.I.P Fund } \\
\hline & Value & T Stat. & Value & T Stat & Value & T. Stat. \\
\hline Constant & 3.38 & 5.13 & 39.74 & 11.75 & 3.30 & 5.88 \\
\hline S\&P500 Return ${ }_{t}$ & 325.4 & 3.74 & 1004.9 & 2.22 & 609.15 & 9.60 \\
\hline Fund's Inflows & 0.88 & 66.65 & 0.55 & 23.56 & 0.82 & 44.76 \\
\hline Corrected $\mathrm{R}^{2}$ & 0.66 & & 0.09 & & 0.53 & \\
\hline Durbin Watson & 2.10 & & 2.05 & & 2.07 & \\
\hline $\begin{array}{l}\text { Number of } \\
\text { Observations }\end{array}$ & 1262 & & 1262 & & 913 & \\
\hline
\end{tabular}

TABLE 9

Funds' outflows and spot market returns:

The functional specification is Outflows $s_{t}=\alpha+\gamma R_{t}+\varepsilon_{t}$, where Outflows are the outflows in the index funds at time $t$ and $R_{t}$ is the percentage return on the $S \& P 500$ spot index at $t-k$. The outflows are standardized dividing them by the average market capitalization in the previous 160 days . To capture all the week effects we considered $\mathrm{k}=5$. The estimations are corrected to control for heteroskedasticity and autocorrelation. All the observations are daily. For Spartan Market Index and Spartan U.S. Equity Index they cover the period 1/4/9312/31/97. For V.I.P.Fund, the period is 5/23/94-12/31/97. The constant and S\&P500 Return ${ }_{t}$ coefficients are divided by $10^{5}$

\section{Dependent Variable: Fund's Outflows}

\begin{tabular}{|c|c|c|c|c|c|c|}
\hline \multirow{2}{*}{$\begin{array}{l}\text { Independent } \\
\text { Variables }\end{array}$} & \multicolumn{2}{|c|}{ Spartan Market Index } & \multicolumn{2}{|c|}{ Spartan U.S. Equity Index } & \multicolumn{2}{|c|}{ V.I.P Fund } \\
\hline & Value & T Stat. & Value & T Stat & Value & T. Stat. \\
\hline Constant & 1.19 & 6.97 & 57.53 & 11.40 & 3.74 & 5.23 \\
\hline $\mathrm{S} \& \mathrm{P} 500$ Return $_{\mathrm{t}}$ & -312.46 & -8.3 & -180.64 & -0.31 & -419.03 & -6.13 \\
\hline Fund's Outflows & 0.84 & 55.74 & 0.073 & 1.74 & 0.27 & 3.54 \\
\hline Corrected $\mathrm{R}^{2}$ & 0.54 & & 0.004 & & 0.15 & \\
\hline Durbin Watson & 2.12 & & 2.00 & & 2.10 & \\
\hline $\begin{array}{l}\text { Number of } \\
\text { Observations }\end{array}$ & 1262 & & 1262 & & 913 & \\
\hline
\end{tabular}


TABLE 10

Funds' inflows and lagged spot returns:

The functional specification is Inflows $\mathrm{I}_{\mathrm{t}}=\alpha+\gamma \sum_{\mathrm{k}=1}^{\mathrm{N}} \mathrm{R}_{\mathrm{t}-\mathrm{k}}+\varepsilon_{\mathrm{t}}$, where Inflows $\mathrm{t}_{\mathrm{t}}$ are the inflows in the index funds at time $t$ and $R_{t-k}$ is the percentage return on the $S \& P 500$ spot index at $t-k$. The inflows are standardized dividing them by the average market capitalization in the previous 160 days. To capture all the week effects we considered $\mathrm{k}=5$. The estimations are corrected to control for heteroskedasticity and autocorrelation. All the observations are daily. For Spartan Market Index and Spartan U.S. Equity Index they cover the period 1/4/9312/31/97. For V.I.P.Fund, the period is 5/23/94-12/31/97. The constant and S\&P500 Return coefficients are divided by $10^{5}$

\section{Independent Variables}

\section{Constant}

S\&P500 Return

S\&P500 Return t-1 $_{1}$

S\&P500 Return t-2 $_{\text {. }}$

S\&P500 Return t 3

S\&P500 Return t-4

S\&P500 Return t-5

Fund's Inflows ${ }_{\mathrm{t}-1}$

Fund's Inflows $\mathrm{t}_{\mathrm{t}-2}$

Fund's Inflows

Fund's Inflows ${ }_{t-4}$

Fund's Inflows

Corrected $\mathrm{R}^{2}$

Durbin Watson

Number of Obs.

\begin{tabular}{cc}
\multicolumn{2}{c}{ De } \\
Spartan Market Index \\
Value & T Stat. \\
0.06 & 2.69 \\
6.90 & 4.34 \\
-0.74 & -0.45 \\
0.21 & 0.13 \\
0.53 & 0.33 \\
4.51 & 2.79 \\
1.69 & 1.06 \\
0.21 & 7.07 \\
0.14 & 5.07 \\
0.069 & 2.37 \\
0.12 & 4.12 \\
0.34 & 12.10 \\
0.69 & \\
& \\
1.99 & \\
1099 &
\end{tabular}

\section{Dependent Variable: Fund's Inflows} Spartan U.S. Equity Index V.I.P Fund

$\begin{array}{cccc}\text { Value } & \text { T Stat } & \text { Value } & \text { T. Stat. } \\ 0.79 & 8.83 & 0.04 & 3.29 \\ 28.45 & 2.58 & 11.67 & 9.01 \\ -16.9 & -1.3 & -2.90 & -1.19 \\ 3.45 & 0.25 & 0.77 & 0.46 \\ 8.77 & 0.63 & -1.44 & -0.86 \\ -2.68 & -0.2 & 1.75 & 1.09 \\ 15.55 & 1.4 & -2.09 & -2.15 \\ 0.69 & 23.22 & 0.88 & 23.98 \\ -0.31 & -8.58 & -0.43 & -8.9 \\ 0.23 & 6.43 & 0.39 & 7.85 \\ -0.13 & -3.65 & -0.14 & -2.97 \\ 0.10 & 3.57 & 0.21 & 5.92 \\ 0.04 & & 0.45 & \end{array}$

2.00
1099

1.98

749 


\section{TABLE 11}

Funds' outflows and lagged spot returns

The functional specification is Outflows $=\alpha+\gamma \sum_{\mathrm{k}=1}^{\mathrm{N}} \mathrm{R}_{\mathrm{t}-\mathrm{k}}+\varepsilon_{\mathrm{t}}$, where Outflows $\mathrm{s}_{\mathrm{t}}$ are the outflows in the index funds at time $t$ and $R_{t-k}$ is the percentage return on the $S \& P 500$ spot index at $t-k$. The outflows are standardized dividing them by the average market capitalization in the previous 160 days. To capture all the week effects we considered $\mathrm{k}=5$. The estimations are corrected to control for heteroskedasticity and autocorrelation. All the observations are daily. For Spartan Market Index and Spartan U.S. Equity Index they cover the period 1/4/9312/31/97. For V.I.P.Fund, the period is 5/23/94-12/31/97. The constant and S\&P500 Return coefficients are divided by $10^{5}$

\begin{tabular}{|c|c|c|c|c|c|c|}
\hline \multirow{3}{*}{$\begin{array}{l}\text { Independent } \\
\text { Variables }\end{array}$} & \multicolumn{6}{|c|}{ Dependent Variable: Fund's Outflows $s_{t}$} \\
\hline & \multicolumn{2}{|c|}{ Spartan Market Index } & \multicolumn{2}{|c|}{ Spartan U.S. Equity Index } & \multicolumn{2}{|c|}{ V.I.P Fund } \\
\hline & Value & T Stat. & Value & T Stat & Value & T. Stat. \\
\hline Constant & 0.024 & 4.04 & 4.73 & 12.5 & 0.03 & 5.64 \\
\hline $\mathrm{S} \& \mathrm{P} 500$ Return $_{\mathrm{t}}$ & -4.65 & -6.55 & 0.17 & 0.18 & -7.96 & -9.79 \\
\hline S\&P500 Return ${ }_{t-1}$ & -3.36 & -4.32 & -3.97 & -0.34 & -2.04 & -2.12 \\
\hline $\mathrm{S} \& \mathrm{P} 500$ Return $_{\mathrm{t}-2}$ & -1.22 & -1.50 & -2.56 & -0.20 & -0.37 & -0.38 \\
\hline $\mathrm{S} \&$ P500 Return ${ }_{\mathrm{t}-3}$ & -1.97 & -2.48 & 2.40 & 0.19 & -1.12 & -1.12 \\
\hline $\mathrm{S} \&$ P500 Return $\mathrm{t}_{-4}$ & -2.04 & -2.58 & 9.90 & 0.84 & -1.28 & -1.32 \\
\hline S\&P500 Return ${ }_{t-5}$ & 1.45 & 1.94 & 10.72 & 1.11 & -2.29 & -2.65 \\
\hline Fund's Outflows $\mathrm{t}_{\mathrm{t}-1}$ & 0.68 & 22.93 & -0.77 & -26.46 & -0.63 & 17.46 \\
\hline Fund's Outflows $\mathrm{t}_{\mathrm{t}-2}$ & -0.15 & -4.18 & -0.56 & -15.57 & -0.22 & -5.6 \\
\hline Fund's Outflows & 0.17 & 4.86 & -0.41 & -10.78 & 0.21 & 5.02 \\
\hline Fund's Outflows $\mathrm{f}_{\mathrm{t}-4}$ & -0.01 & -0.55 & -0.31 & -8.77 & -0.05 & -1.29 \\
\hline \multirow[t]{2}{*}{ Fund's Outflows -5} & 0.22 & 7.82 & -0.26 & -9.10 & 0.11 & 3.22 \\
\hline & 0.53 & & 0.04 & & 0.21 & \\
\hline \multicolumn{7}{|l|}{ Corrected $\mathrm{R}^{2}$} \\
\hline Durbin Watson & 1.99 & & 1.99 & & 2.02 & \\
\hline Number of Obs. & 1099 & & 1099 & & 749 & \\
\hline
\end{tabular}


TABLE 12

Funds' inflows and lagged futures returns

The functional specification is Inflows $s_{t}=\alpha+\beta \sum_{\mathrm{k}=0}^{\mathrm{N}} \mathrm{R}_{\mathrm{t}-\mathrm{k}}+\gamma \sum_{\mathrm{k}=1}^{\mathrm{N}}$ Inflows $_{\mathrm{t}-\mathrm{k}}+\varepsilon_{\mathrm{t}}$, where Inflows represents the inflows in the index funds at time $t$ and $R_{t-k}$ is the percentage return on the S\&P 500 futures index at $t-k$. To capture all the week effects we considered $\mathrm{k}=5$. The estimations are White-corrected to control for

heteroskedasticity and autocorrelation. All the observations are daily. For Spartan Market Index and Spartan U.S. Equity Index they cover the period 1/4/93-12/31/97. For V.I.P.Fund, the period is 5/23/94-12/31/97. The inflows are standardized dividing them by the average market capitalization in the previous 160 days.

Independent
Variables

Constant

$\mathrm{S} \& \mathrm{P} 500$ Return $_{\mathrm{t}}$

S\&P500 Return 1

S\&P500 Return t-2 $_{1-3}$

S\&P500 Return t-3 $_{1}$

S\&P500 Return t-4 $_{4}$

S\&P500 Return ${ }_{t-5}$

Fund's Inflows $\mathrm{t}_{\mathrm{t}-1}$

Fund's Inflows

Fund's Inflows

Fund's Inflows

Fund's Inflows -5

Corrected $\mathrm{R}^{2}$

Durbin Watson

Number of

Observations

\section{Dependent Variable: Fund's Inflows ${ }_{t}$}

Spartan Market Index

Spartan U.S. Equity Index

V.I.P Fund

$\begin{array}{cccccc}\text { Value } & \text { T Stat } & \text { Value } & \text { T Stat } & \text { Value } & \text { T Stat } \\ 0.06 & 2.75 & 0.80 & 8.87 & 0.04 & 3.23 \\ 6.82 & 4.78 & 29.61 & 3.01 & 11.30 & 9.89 \\ -0.30 & -0.20 & -13.44 & -1.19 & -2.40 & -1.75 \\ -0.80 & -0.54 & -2.34 & -0.20 & 0.57 & 0.39 \\ 0.30 & 0.20 & 12.66 & 1.079 & -1.21 & -0.84 \\ 3.43 & 2.33 & -5.75 & -0.51 & 1.45 & 1.05 \\ 1.80 & 1.25 & 18.21 & 1.84 & -2.51 & 2.11 \\ 0.21 & 7.45 & 0.69 & 23.00 & 0.89 & 24.20 \\ 0.15 & 5.41 & -0.30 & -8.33 & -0.44 & -8.99 \\ 0.06 & 2.24 & 0.22 & 6.19 & 0.39 & 7.83 \\ 0.11 & 4.02 & -0.12 & -3.44 & -0.15 & -3.14 \\ 0.35 & 12.16 & 0.10 & 3.43 & 0.22 & 6.12 \\ 0.69 & & 0.04 & & 0.46 & \end{array}$

1.99

1.99

1.98

750 
TABLE 13

Funds' outflows and lagged futures returns

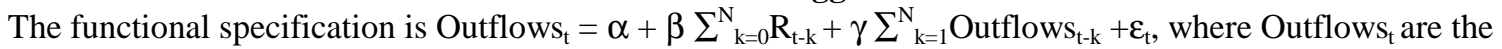
outflows in the index funds at time $t$ and $\mathrm{R}_{\mathrm{t}-\mathrm{k}}$ is the percentage return on the S\&P 500 futures index at $\mathrm{t}-\mathrm{k}$. To capture all the week effects we considered $\mathrm{k}=5$. The estimations are White-corrected to control for

heteroskedasticity and autocorrelation. All the observations are daily. For Spartan Market Index and Spartan U.S.

Equity Index they cover the period 1/4/93-12/31/97. For V.I.P.Fund, the period is 5/23/94-12/31/97. The

outflows are standardized dividing them by the average market capitalization in the previous 160 days.

\begin{tabular}{|c|c|c|c|c|c|c|}
\hline \multirow{3}{*}{$\begin{array}{l}\text { Independent } \\
\text { Variables }\end{array}$} & \multicolumn{6}{|c|}{ Dependent Variable: Fund s Outflows $s_{t}$} \\
\hline & \multicolumn{2}{|c|}{ Spartan Market Index } & \multicolumn{2}{|c|}{ Spartan U.S. Equity Index } & \multicolumn{2}{|c|}{ V.I.P Fund } \\
\hline & Value & T Stat & Value & T Stat & Value & T Stat \\
\hline Constant & 0.023 & 3.98 & 4.73 & 12.56 & 0.04 & 5.60 \\
\hline S\&P500 Return & -3.38 & -5.31 & 4.44 & 0.51 & -6.38 & -8.77 \\
\hline S\&P500 Return ${ }_{\mathrm{t}-1}$ & -4.24 & -6.30 & -1.56 & -0.14 & -0.02 & -0.025 \\
\hline${\mathrm{S} \& P 500 \text { Return }_{\mathrm{t}-2}}$ & 1.09 & 1.58 & -1.59 & -0.13 & 0.44 & 0.53 \\
\hline S\&P500 Return t-3 & -1.99 & -2.88 & -1.94 & -0.16 & -1.00 & -1.19 \\
\hline S\&P500 Return & -1.57 & -2.28 & 8.07 & 0.74 & -1.49 & -1.79 \\
\hline 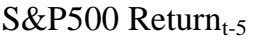 & 1.68 & 2.57 & 10.30 & 1.19 & 2.27 & 2.97 \\
\hline Funds'Outflows $_{\mathrm{t}-1}$ & 0.66 & 22.47 & -0.77 & -26.44 & 0.62 & 17.01 \\
\hline Funds'Outflows $\mathrm{t}_{\mathrm{t}-2}$ & -0.13 & -3.78 & -0.56 & -15.54 & -0.20 & -4.66 \\
\hline Funds'Outflows $\mathrm{t}_{\mathrm{t}-3}$ & 0.16 & 4.68 & -0.41 & -10.77 & 0.20 & 4.85 \\
\hline Funds'Outflows ${ }_{t-4}$ & -0.001 & -0.22 & -0.31 & -8.76 & -0.04 & -1.01 \\
\hline Funds'Outflows t- 5 & 0.22 & 7.71 & -0.26 & -9.11 & 0.11 & 3.13 \\
\hline & 0.04 & & 0.04 & & 0.20 & \\
\hline Corrected $\mathrm{R}^{2}$ & & & & & & \\
\hline Durbin Watson & 1.99 & & 1.99 & & 2.02 & \\
\hline $\begin{array}{l}\text { Number of } \\
\text { Observations }\end{array}$ & 1099 & & 1099 & & 750 & \\
\hline
\end{tabular}


TABLE 14

Funds' inflows and open interest:

The functional specification is Inflows $s_{t}=\alpha+\beta$ Return $_{t}+\gamma$ Open Interest $t_{t}+\delta$ Inflows $_{t-1}+\varepsilon_{t}$, where Inflows $s_{t}$ are the inflows in the index funds at time $t, R_{t}$ is the percentage return on the $S \& P 500$ spot index at $t$. Open Interest is the number of outstanding contracts (shorts and longs) on the Futures on the S\&P 500. It is standardized dividing it by a rolling average of market capitalization in the previous 160 days. The estimations are corrected to control for heteroskedasticity and autocorrelation. All the observations are daily. For Spartan Market Index and Spartan U.S. Equity Index they cover the period 1/4/93-12/31/97. For V.I.P.Fund, the period is 5/23/94-12/31/97. The inflows are standardized dividing them by the average market capitalization in the previous 160 days. The Open Interest coefficients are divided by $10^{6}$

\section{Dependent Variable: Fund's Inflows $s_{t}$}

\begin{tabular}{|c|c|c|c|c|c|c|}
\hline \multirow{2}{*}{$\begin{array}{l}\text { Independent } \\
\text { Variables }\end{array}$} & \multicolumn{2}{|c|}{ Spartan Market Index } & \multicolumn{2}{|c|}{ Spartan U.S. Equity Index } & \multicolumn{2}{|c|}{ V.I.P Fund } \\
\hline & Value & T Stat & Value & T Stat & Value & T Stat \\
\hline Constant & 0.06 & 1.41 & 1.18 & 4.23 & 0.16 & 0.05 \\
\hline Open Interest $t_{t}$ & 0.03 & 0.47 & 0.0001 & 0.0062 & 0.01 & 0.12 \\
\hline S\&P500 Return ${ }_{t}$ & 5.93 & 3.58 & 25.24 & 2.42 & 2.23 & 0.87 \\
\hline Fund's Inflows ${ }_{t-1}$ & 0.86 & 58.00 & 0.41 & 14.94 & 0.74 & 30.31 \\
\hline Corrected $\mathrm{R}^{2}$ & 0.62 & & 0.03 & & 0.35 & \\
\hline Durbin Watson & 2.10 & & 2.0 & & 2.09 & \\
\hline $\begin{array}{l}\text { Number of } \\
\text { Observations }\end{array}$ & 1103 & & 1103 & & 751 & \\
\hline
\end{tabular}

TABLE 15

Funds' outflows and open interest:

The functional specification is Outflows $\mathrm{t}_{\mathrm{t}}=\alpha+\beta$ Return $_{\mathrm{t}}+\gamma$ Open Interest $\mathrm{t}_{\mathrm{t}}+\delta$ Outflows $_{\mathrm{t}-1}+\varepsilon_{\mathrm{t}}$, where Outflows $\mathrm{s}_{\mathrm{t}}$ are the outflows in the index funds at time $t, R_{t}$ is the percentage return on the $S \& P 500$ spot index at $t$ and Open Interest $t_{t}$ is the number of outstanding contracts (shorts and longs) on the Futures on the S\&P 500. It is standardized dividing it by a rolling average of market capitalization in the previous 160 days.. The estimations are corrected to control for heteroskedasticity and autocorrelation. All the observations are daily. For Spartan Market Index and Spartan U.S. Equity Index they cover the period 1/4/93-12/31/97. For V.I.P.Fund, the period is $5 / 23 / 94-12 / 31 / 97$. The outflows are standardized dividing them by the average market capitalization in the previous 160 days. The Open Interest coefficients are divided by $10^{6}$

Dependent Variable: Fund's Outflows

\begin{tabular}{|c|c|c|c|c|c|c|}
\hline \multirow{2}{*}{$\begin{array}{l}\text { Independent } \\
\text { Variables }\end{array}$} & \multicolumn{2}{|c|}{ Spartan Market Index } & \multicolumn{2}{|c|}{ Spartan U.S. Equity Index } & \multicolumn{2}{|c|}{ V.I.P Fund } \\
\hline & Value & T Stat & Value & T Stat & Value & T Stat \\
\hline Constant & -0.004 & -0.02 & 0.76 & 2.77 & -0.068 & -1.90 \\
\hline Open Interest $t_{t}$ & 0.09 & 3.00 & 0.7 & 1.51 & 0.24 & 4.10 \\
\hline S\&P500 Return & -6.00 & -8.34 & -3.59 & -0.38 & -2.53 & -1.54 \\
\hline Fund's Outflows $\mathrm{t}_{\mathrm{t}-1}$ & 0.78 & 42.26 & 0.17 & 6.00 & 0.42 & 12.69 \\
\hline & 0.45 & & 0.00 & & 0.09 & \\
\hline Corrected $\mathrm{R}^{2}$ & & & & & & \\
\hline Durbin Watson & 2.10 & & 2.00 & & 2.02 & \\
\hline $\begin{array}{l}\text { Number of } \\
\text { Observations }\end{array}$ & 1103 & & 1103 & & 751 & \\
\hline
\end{tabular}


TABLE 16

Funds' inflows and volatility:

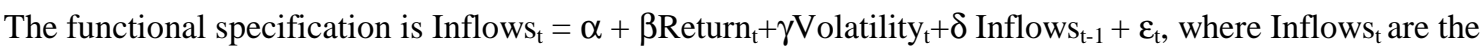
inflows in the index funds at time $t, R_{t}$ is the percentage return on the S\&P 500 spot index at $t$ and Volatility is the implied volatility on the S\&P500 derived from the options written on it, at the money and with the shortest maturity. The estimations are corrected to control for autocorrelation. All the observations are daily. For Spartan Market Index and Spartan U.S. Equity Index they cover the period 1/4/93-12/31/97. For V.I.P.Fund, the period is $5 / 23 / 94-12 / 31 / 97$. The inflows are standardized dividing them by the average market capitalization in the previous 160 days.

\section{Dependent Variable: Fund's Inflows}

\begin{tabular}{|c|c|c|c|c|c|c|}
\hline \multirow{2}{*}{$\begin{array}{l}\text { Independent } \\
\text { Variables }\end{array}$} & \multicolumn{2}{|c|}{ Spartan Market Index } & \multicolumn{2}{|c|}{ Spartan U.S. Equity Index } & \multicolumn{2}{|c|}{ V.I.P Fund } \\
\hline & Value & T Stat & Value & T Stat & Value & T Stat \\
\hline Constant & -0.08 & -2.30 & 0.48 & 2.33 & 0.01 & 0.43 \\
\hline Volatility $_{t}$ & 1.58 & 5.24 & 6.20 & 3.87 & 1.42 & 4.62 \\
\hline S\&P500 Return & 5.87 & 3.56 & 24.39 & 2.35 & 2.78 & 1.09 \\
\hline Fund's Inflows ${ }_{t-1}$ & 0.80 & 45.08 & 0.37 & 13.40 & 0.67 & 24.9 \\
\hline & 0.63 & & 0.043 & & 0.37 & \\
\hline Corrected $\mathrm{R}^{2}$ & & & & & & \\
\hline Durbin Watson & 2.07 & & 2.00 & & 2.06 & \\
\hline $\begin{array}{l}\text { Number of } \\
\text { Observations }\end{array}$ & 1103 & & 1103 & & 751 & \\
\hline
\end{tabular}

TABLE 17

Funds' outflows and volatility:

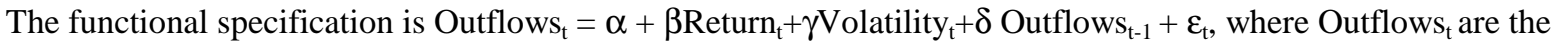
outflows in the index funds at time $t, \mathrm{R}_{\mathrm{t}}$ is the percentage return on the $\mathrm{S} \& \mathrm{P} 500$ spot index at $\mathrm{t}$ and Volatility $\mathrm{y}_{\mathrm{t}}$ is the implied volatility on the S\&P500 derived from the options written on it, at the money and with the shortest maturity. The estimations are corrected to control for autocorrelation. All the observations are daily. For Spartan Market Index and Spartan U.S. Equity Index they cover the period 1/4/93-12/31/97. For V.I.P.Fund, the period is $5 / 23 / 94-12 / 31 / 97$. The outflows are standardized dividing them by the average market capitalization in the previous 160 days.

\section{Dependent Variable: Fund's Outflows}

\begin{tabular}{|c|c|c|c|c|c|c|}
\hline \multirow{2}{*}{$\begin{array}{l}\text { Independent } \\
\text { Variables }\end{array}$} & \multicolumn{2}{|c|}{ Spartan Market Index } & \multicolumn{2}{|c|}{ Spartan U.S. Equity Index } & \multicolumn{2}{|c|}{ V.I.P Fund } \\
\hline & Value & T Stat & Value & T Stat & Value & T Stat \\
\hline Constant & -0.077 & -5.7 & -0.59 & -2.86 & -0.052 & -1.92 \\
\hline Volatility $_{t}$ & 1.28 & 9.26 & 4.85 & 3.07 & 1.01 & 5.09 \\
\hline S\&P500 Return & -5.96 & -8.44 & -3.97 & -0.40 & -2.37 & -1.40 \\
\hline Fund's Outflows t-1 & 0.64 & 27.97 & 0.15 & 5.26 & 0.37 & 10.88 \\
\hline & 0.49 & & 0.006 & & 0.10 & \\
\hline Corrected $\mathrm{R}^{2}$ & & & & & & \\
\hline Durbin Watson & 2.06 & & 1.99 & & 2.01 & \\
\hline $\begin{array}{l}\text { Number of } \\
\text { Observations }\end{array}$ & 1103 & & 1103 & & 751 & \\
\hline
\end{tabular}


TABLE 18

Funds' inflows and analysts' recommendations:

The functional specification is Inflows $s_{t}=\alpha+\beta$ Arecommendation $_{t}+\gamma$ Information $_{t}+\delta$ Inflows $_{t-1}+\varepsilon_{t}$, where Inflows are the inflows in the index funds at time $t$ and Arecommendation ${ }_{t}$ is the percentage of the portfolio to be held in stocks, calculated as average of daily analysts' recommendations. It is the average of $\mathrm{t}$ and $\mathrm{t}-1$ recommendations. Information ${ }_{\mathrm{t}}$ represents the amount of information publicly available on the market and is composed of the 3 Month Tbill rate, the Dividend Yield, the Term spread and the Quality Spread. The estimations are corrected to control for autocorrelation. All the observations are daily. For Spartan Market Index and Spartan U.S. Equity Index they cover the period 1/4/93-12/31/97. . The inflows are standardized dividing them by the average market capitalization in the previous 160 days. For V.I.P.Fund, the period is 5/23/94-12/31/97.

\begin{tabular}{|c|c|c|c|c|c|c|}
\hline \multirow{2}{*}{$\begin{array}{l}\text { Independent } \\
\text { Variables }\end{array}$} & \multicolumn{6}{|c|}{$\begin{array}{l}\text { Dependent Variable: Fund's Inflows } \\
\text { Spartan U.S. Equity Index }\end{array}$} \\
\hline & Value & T Stat. & Value & T Stat. & Value & T Stat. \\
\hline Constant & 0.82 & 3.10 & 3.00 & 1.85 & 0.31 & 0.57 \\
\hline Arecommendation $_{\mathrm{t}}$ & 0.42 & 2.45 & 1.19 & 1.13 & 0.16 & 1.00 \\
\hline 3 Month T.Bill rate ${ }_{\mathrm{t}}$ & 0.04 & 2.31 & 0.04 & 0.33 & 0.10 & 1.15 \\
\hline Dividend Yield $_{\mathrm{t}}$ & -0.45 & -7.38 & -1.06 & -3.12 & -0.45 & -6.82 \\
\hline Term spread $_{t}$ & 0.07 & 3.19 & 0.15 & 1.05 & -0.42 & -1.37 \\
\hline Quality Spread $_{t}$ & 0.18 & 0.94 & 0.40 & 0.32 & -0.42 & -1.37 \\
\hline \multirow[t]{2}{*}{ Fund's Inflows } & 0.62 & 25.86 & 0.31 & 10.71 & 0.39 & 11.0 \\
\hline & 0.66 & & 0.07 & & 0.40 & \\
\hline \multicolumn{7}{|l|}{ Corrected $\mathrm{R}^{2}$} \\
\hline Durbin Watson & 2.02 & & 2.00 & & 1.97 & \\
\hline Number of Obs. & 1103 & & 1103 & & 753 & \\
\hline
\end{tabular}

TABLE 19

Funds' outflows and analysts' recommendations:

The functional specification is Outflows $s_{t} \alpha+\beta$ Arecommendation $_{t}+\gamma$ Information $_{t}+\delta$ Outflows $_{t-1}+\varepsilon_{t}$, where Outflows $_{t}$ are the outflows in the index funds at time $t$ and Arecommendation ${ }_{t}$ is the percentage of the portfolio to be held in stocks, calculated as average of daily analysts' recommendations. It is the average of $t$ and t-1 recommendations. Information ${ }_{t}$ represents the amount of information publicly available on the market and is composed of the 3 Month Tbill rate, the Dividend Yield, the Term spread and the Quality Spread. The estimations are corrected to control for autocorrelation. All the observations are daily. For Spartan Market Index and Spartan U.S. Equity Index they cover the period 1/4/93-12/31/97. For V.I.P.Fund, the period is 5/23/94$12 / 31 / 97$. Outflows are standardized dividing them by the average market capitalization in the previous 160 days.

\begin{tabular}{|c|c|c|c|c|c|c|}
\hline \multirow{3}{*}{$\begin{array}{l}\text { Independent } \\
\text { Variables }\end{array}$} & \multicolumn{6}{|c|}{ Dependent Variable: Fund's Outflows $s_{t}$} \\
\hline & \multicolumn{2}{|c|}{ Spartan Market Index } & \multicolumn{2}{|c|}{ partan U.S. Equity Index } & \multicolumn{2}{|c|}{ V.I.P Fund } \\
\hline & Value & T Stat. & Value & T Stat. & Value & T Stat. \\
\hline Constant & 1.28 & 9.29 & 4.91 & 2.30 & 1.56 & 3.30 \\
\hline Arecommendation $_{\mathrm{t}}$ & -0.26 & -3.25 & -0.90 & -0.65 & -0.43 & -3.00 \\
\hline 3 Month T.Bill rate & -0.01 & -1.96 & -0.01 & -0.06 & -0.03 & -0.40 \\
\hline Dividend Yield $_{t}$ & -0.35 & -11.39 & -1.39 & -3.12 & -0.31 & -5.72 \\
\hline Term spread $_{t}$ & 0.03 & 3.29 & 0.31 & 1.65 & 0.07 & 3.22 \\
\hline Quality Spread $_{\mathrm{t}}$ & 0.25 & 2.75 & -0.02 & -0.01 & 0.68 & 2.60 \\
\hline Fund's Outflows & 0.43 & 15.98 & -0.15 & -5.12 & -0.12 & -3.30 \\
\hline Corrected $\mathrm{R}^{2}$ & 0.50 & & 0.01 & & 0.16 & \\
\hline Durbin Watson & 2.01 & & 2.00 & & 2.00 & \\
\hline Number of Obs. & 1103 & & 1103 & & 753 & \\
\hline
\end{tabular}


TABLE 20

Funds' inflows and analysts' recommendations:

The functional specification is Inflows $s_{t}=\alpha+\beta$ Srecommendation $_{t}+\gamma$ Information $_{t}+\delta$ Inflows $_{t-1}+\varepsilon_{t}$, where Inflows are the inflows in the index funds at time $t$ and and Srecommendation ${ }_{t}$ represents analysts' dispersion of beliefs. It is the standard deviation of analysts' recommendations about the percentage of the portfolio to be held in stocks. It is the average of $t$ and $t-1$ values. Information ${ }_{t}$ represents the amount of information publicly available on the market and is composed of the 3 Month Tbill rate, the Dividend Yield, the Term spread and the Quality Spread. The estimations are corrected to control for autocorrelation. All the observations are daily. For Spartan Market Index and Spartan U.S. Equity Index they cover the period 1/4/93-12/31/97. For V.I.P.Fund, the period is $5 / 23 / 94-12 / 31 / 97$. The inflows are standardized dividing them by the average market capitalization in the previous 160 days.

\begin{tabular}{|c|c|c|c|c|c|c|}
\hline \multirow{2}{*}{$\begin{array}{l}\text { Independent } \\
\text { Variables }\end{array}$} & \multicolumn{6}{|c|}{$\begin{array}{l}\text { Dependent Variable: Fund's Inflows } \mathbf{s}_{\mathbf{t}} \\
\text { Spartan U.S. Equity Index }\end{array}$} \\
\hline & Value & T Stat. & Value & T Stat. & Value & T Stat. \\
\hline Constant & 1.70 & 7.37 & 4.86 & 3.74 & 0.80 & 1.60 \\
\hline Srecommendation $_{\mathrm{t}}$ & -1.16 & -4.02 & -1.94 & -1.16 & -0.69 & -2.87 \\
\hline 3 Month T.Bill rate & 0.03 & 1.52 & 0.0001 & 0.001 & 0.09 & 1.06 \\
\hline Dividend Yield $t_{t}$ & -0.40 & -6.76 & -1.04 & -3.02 & -0.42 & -6.04 \\
\hline Term spread $_{t}$ & 0.05 & 2.41 & 0.09 & 0.69 & 0.05 & 1.85 \\
\hline Quality Spread $_{t}$ & 0.18 & 0.94 & 0.25 & 0.20 & -0.39 & -1.23 \\
\hline Fund's Inflows ${ }_{t-1}$ & 0.59 & 24.13 & 0.31 & 10.71 & 0.33 & 9.27 \\
\hline Corrected $\mathrm{R}^{2}$ & 0.68 & & 0.07 & & 0.40 & \\
\hline Durbin Watson & 2.02 & & 2.00 & & 1.96 & \\
\hline Number of Obs. & 1103 & & 1103 & & 753 & \\
\hline
\end{tabular}

TABLE 21

Funds' outflows and analysts' recommendations:

The functional specification is Outflows $s_{t}=\alpha+\beta$ Arecommendation $_{t}+\gamma$ Information $_{t}+\delta$ Outflows $_{t-1}+\varepsilon_{t}$, where Outflows $_{\mathrm{t}}$ are the outflows in the index funds at time $t$ and and Srecommendation $\mathrm{n}_{\mathrm{t}}$ represents analysts' dispersion of beliefs. It is the standard deviation of analysts' recommendations about the percentage of the portfolio to be held in stocks. It is the average of $t$ and $t-1$ values. Information ${ }_{t}$ represents the amount of information publicly available on the market and is composed of the 3 Month Tbill rate, the Dividend Yield, the Term spread and the Quality Spread. The estimations are corrected to control for autocorrelation. All the observations are daily. For Spartan Market Index and Spartan U.S. Equity Index they cover the period 1/4/93-12/31/97. For V.I.P.Fund, the period is $5 / 23 / 94-12 / 31 / 97$. Outflows are standardized dividing them by the average market capitalization in the previous 160 days.

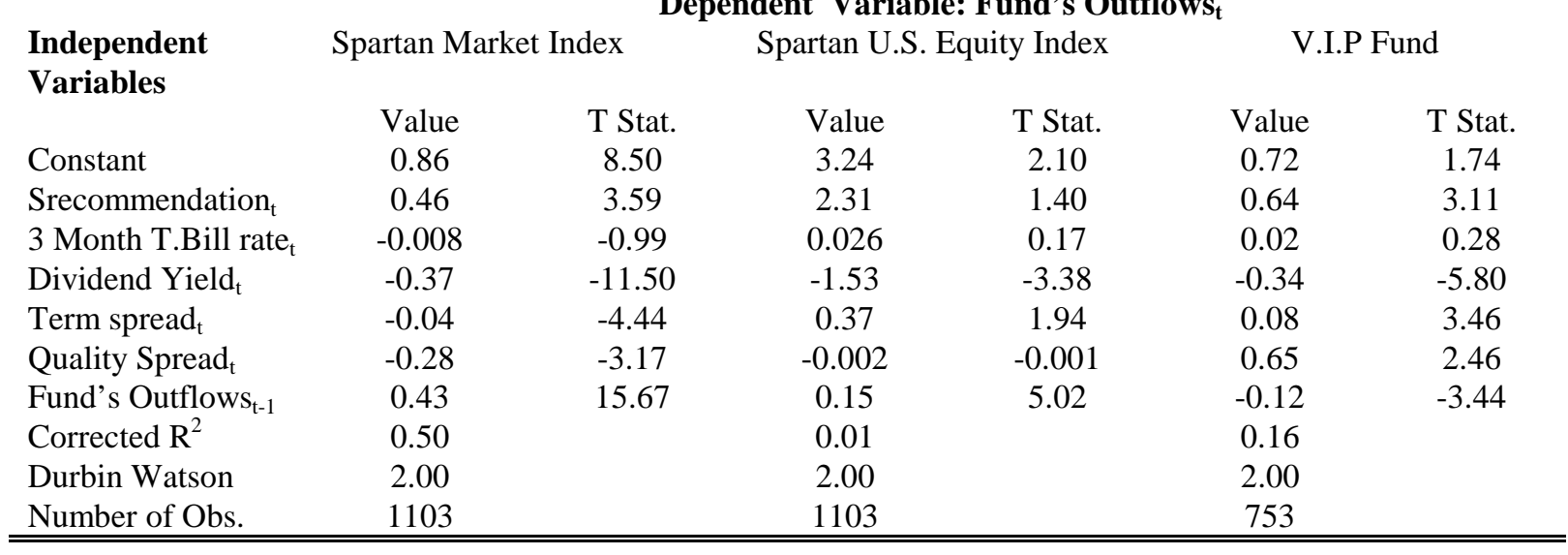


TABLE 22

Spread SP500-SP400 and funds' flows

(Spot spread)

The functional specification is $R_{t}=\alpha+\gamma$ Flows $_{t}+\varepsilon_{t}$, where $R_{t}$ is the difference between the percentage return on

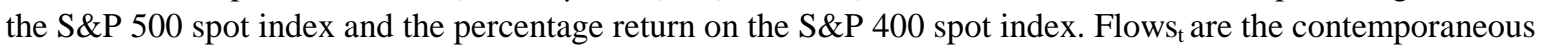
inflows in the index funds. The flows are the net flows (inflows-outflows) and are standardized dividing them by the average market capitalization in the previous 160 days. The estimations are corrected to control for autocorrelation. All the observations are daily. For Spartan Market Index and Spartan U.S. Equity Index they cover the period 1/4/93-12/31/97. For V.I.P.Fund, the period is 5/23/94-12/31/97. Flows' values are divided by $1,000,000$.

\section{Dependent Variable: S\&P 500 Spot Return - S\&P 400 Spot Return}

\begin{tabular}{|c|c|c|c|c|c|c|}
\hline \multirow{2}{*}{$\begin{array}{l}\text { Independent } \\
\text { Variables }\end{array}$} & \multicolumn{2}{|c|}{ Spartan Market Index } & \multicolumn{2}{|c|}{ Spartan U.S. Equity Index } & \multicolumn{2}{|c|}{ V.I.P Fund } \\
\hline & Value & T Stat. & Value & T Stat & Value & T. Stat. \\
\hline Constant & 104 & 0.62 & 9543 & 0.64 & -7.5 & -0.02 \\
\hline Fund's Flows ${ }_{t}$ & 1258 & 3.36 & 117 & 1.92 & 2550 & 5.46 \\
\hline Fund's Flows ${ }_{\mathrm{t}-1}$ & 340 & -0.83 & 32 & 0.51 & -1116 & -2.20 \\
\hline Fund's Flows ${ }_{\mathrm{t}-2}$ & -570 & -1.39 & 67 & 1.07 & -547 & -1.08 \\
\hline Fund's Flows ${ }_{t-3}$ & -221 & -0.54 & 75 & -1.19 & -633 & -1.25 \\
\hline Fund's Flows ${ }_{\mathrm{t}-4}$ & 123 & 0.30 & 100 & 1.59 & 415 & 0.82 \\
\hline Fund's Flows ${ }_{t-5}$ & -309 & -0.82 & 124 & -2.01 & -409 & -0.86 \\
\hline Corrected $\mathrm{R}^{2}$ & 0.03 & & & 0.03 & 0.05 & \\
\hline Durbin Watson & 2.00 & & & 2.00 & 1.99 & \\
\hline Number of Obs. & 1099 & & & 1099 & 749 & \\
\hline
\end{tabular}

TABLE 23

Spread SP500-SP400 and funds' flows (Futures spread)

The functional specification is $R_{t}=\alpha+\gamma$ Flows $_{t}+\varepsilon_{t}$, where $R_{t}$ is the difference between the percentage return on the S\&P 500 futures index and the percentage return on the S\&P 400 futures index. Flows $\mathrm{s}_{\mathrm{t}}$ are the contemporaneous outflows in the index funds. The flows are the net flows (inflows-outflows) and are standardized dividing them by the average market capitalization in the previous 160 days. The estimations are White-corrected to control for heteroskedasticity and autocorrelation. All the observations are daily. For Spartan Market Index and Spartan U.S. Equity Index they cover the period 1/4/93-12/31/97. For V.I.P.Fund, the period is 5/23/94-12/31/97. Flows' values are divided by 1,000,000.

Independent
Variables

Constant

Fund's Flows

Fund's Flows $\mathrm{t}_{\mathrm{t}-1}$

Fund's Flows $\mathrm{t}_{\mathrm{t}-2}$

Fund's Flows

Fund's Flows -4

Fund's Flows $t-5$

Corrected $\mathrm{R}^{2}$

Durbin Watson

Number of Obs.
Dependent Variable: S\&P 500 Futures Return - S\&P 400 Futures Return Spartan Market Index $\quad$ Spartan U.S. Equity Index VIP Fund

\begin{tabular}{cccccc} 
Value & T Stat. & Value & T Stat & Value & T. Stat. \\
138 & 0.79 & 24 & 0.16 & 27 & 0.94 \\
734 & 1.92 & 72 & 1.16 & 1806 & 3.63 \\
215 & -0.52 & 17 & 0.26 & -120 & -0.22 \\
295 & -0.72 & 109 & 1.72 & -1267 & -2.33 \\
249 & -0.60 & 112 & -1.77 & -387 & -0.71 \\
315 & 0.77 & 88 & 1.38 & 789 & 1.44 \\
425 & -1.10 & 79 & -1.25 & -638 & -1.26 \\
0.01 & & 0.02 & & 0.04 & \\
2.00 & & 2.00 & & 2.00 & \\
1099 & & 1099 & & 749 & \\
\hline
\end{tabular}




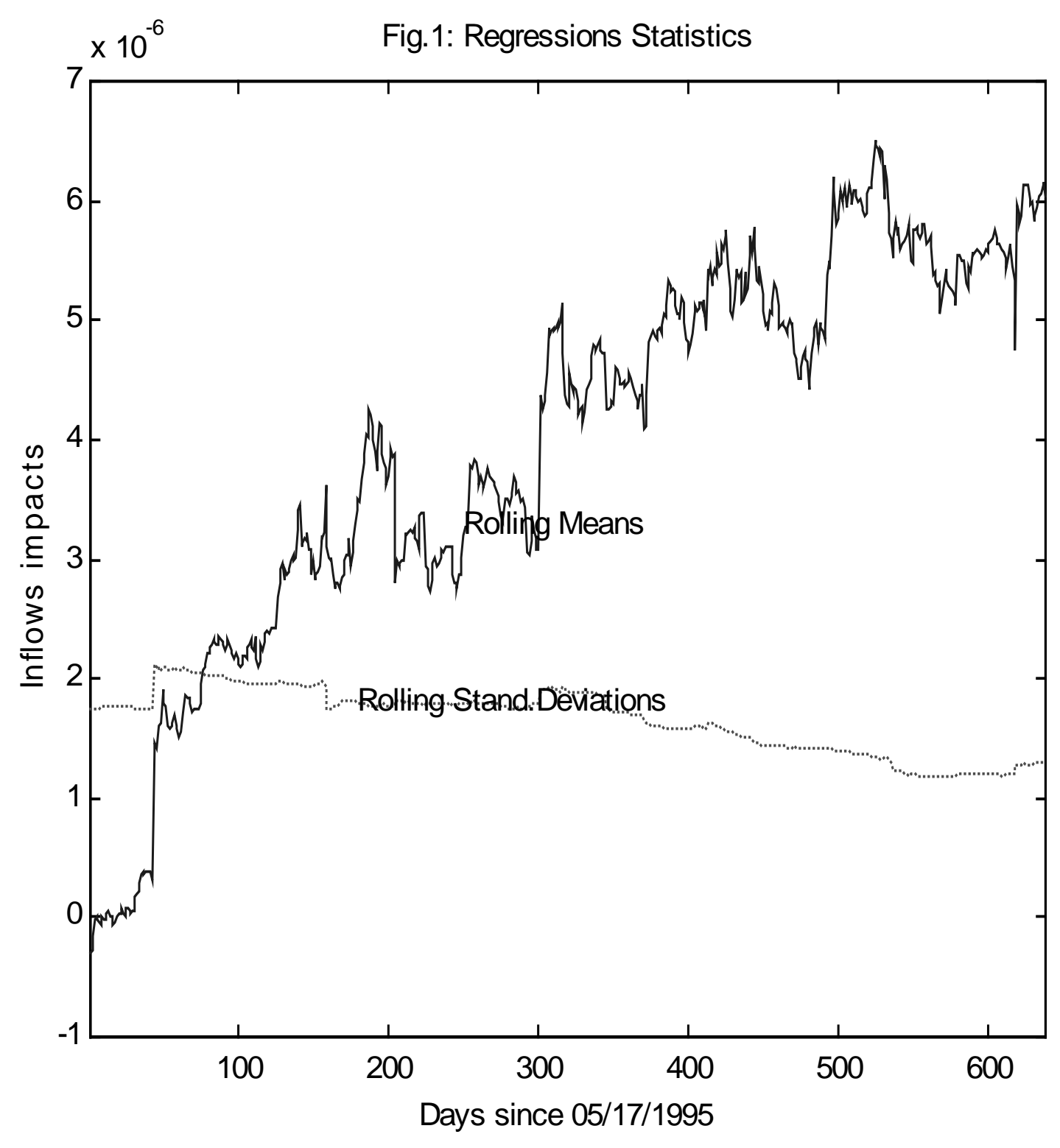


Fig.2:Fund Flows and Stock Indexes: results from fixed coefficients regression

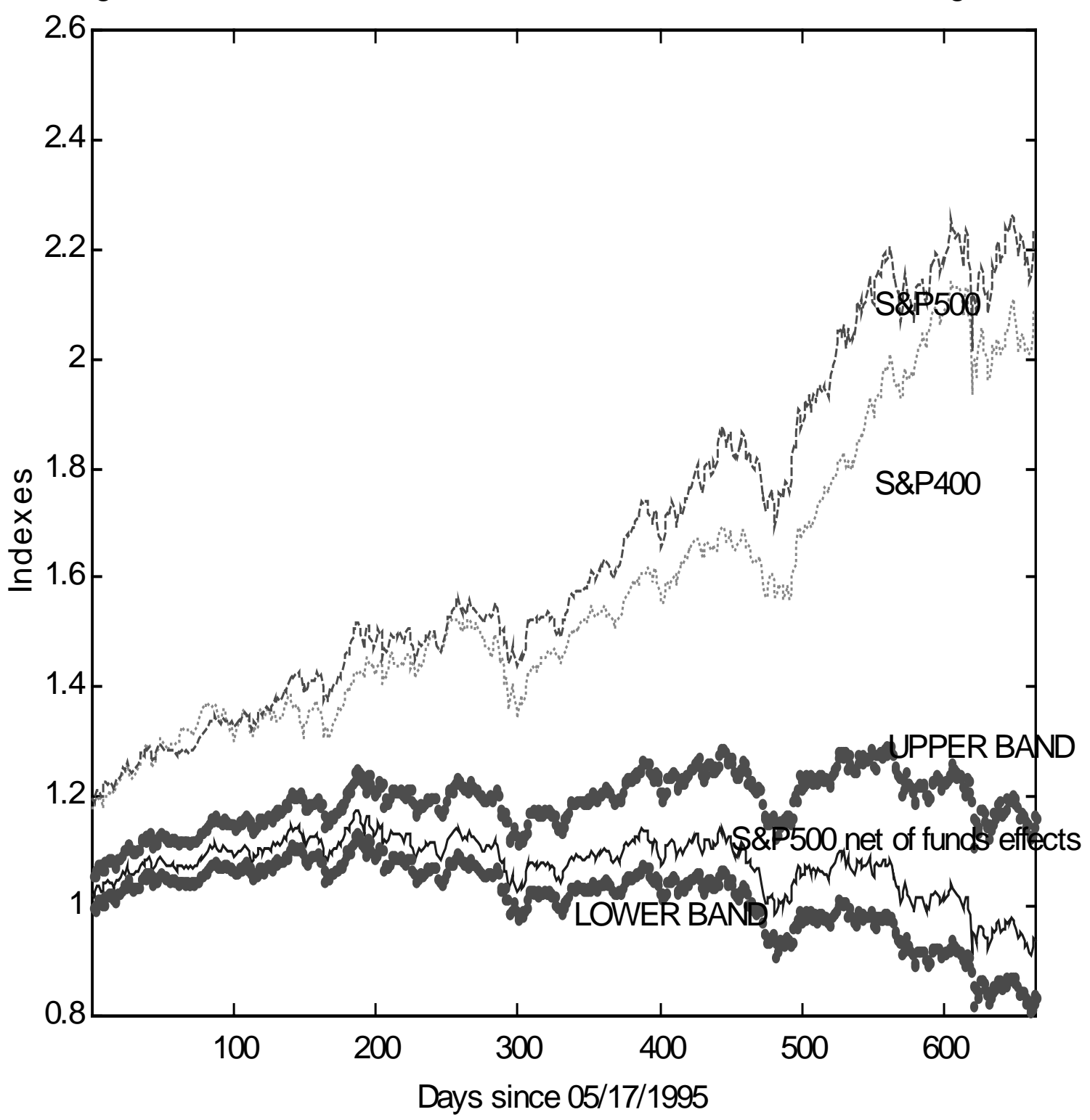


Fig.3:Fund Flows and Stock Indexes: results from rolling coefficients regression

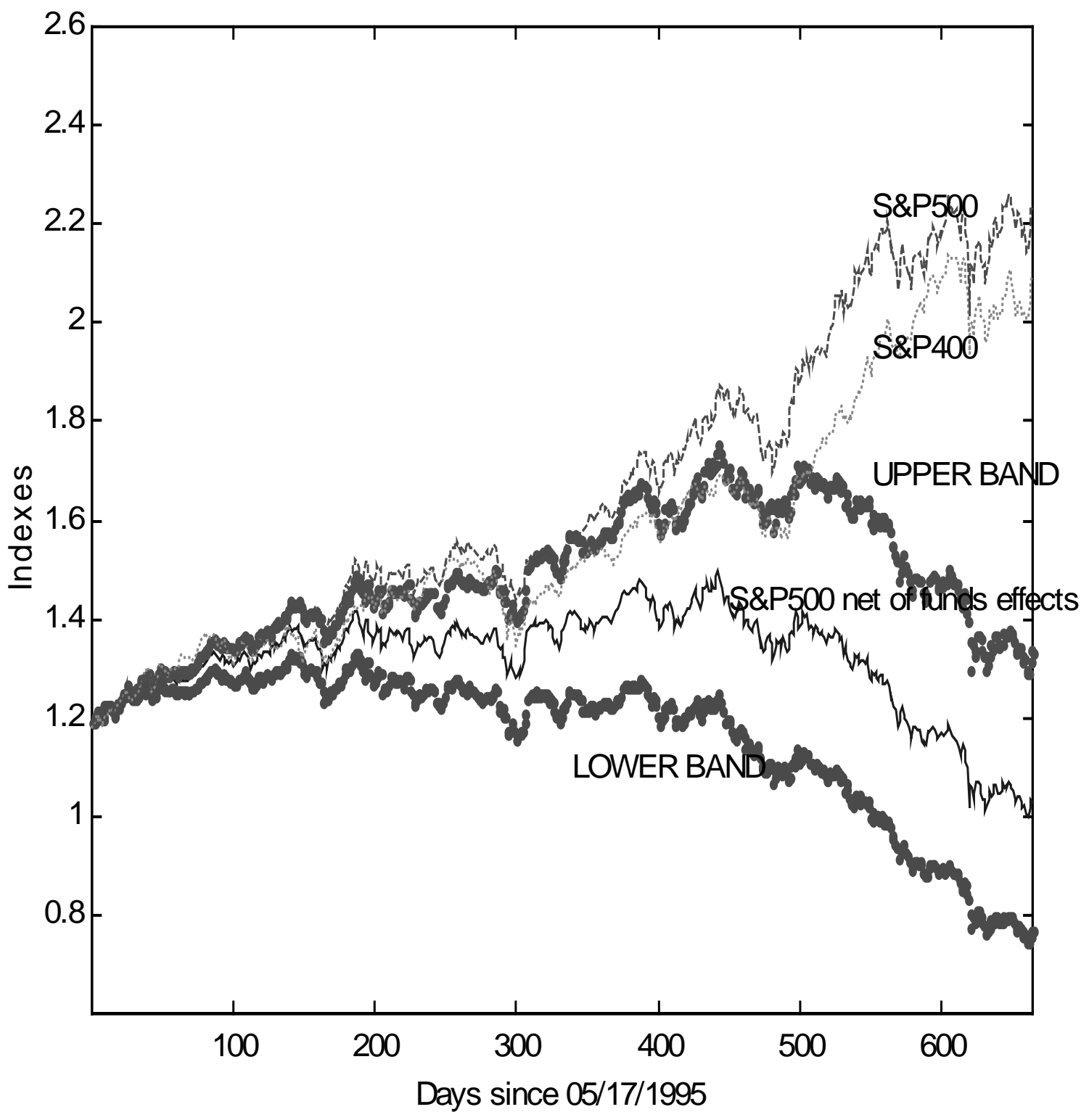

